\title{
Current status and advances of fish vaccines in Malaysia
}

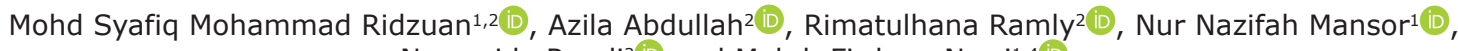 \\ Norazsida Ramli ${ }^{3}$ iD and Mohd. Firdaus-Nawi ${ }^{1,4}$ (i)
}

\begin{abstract}
1. Department of Marine Science, Kulliyyah of Science, International Islamic University Malaysia, Bandar Indera Mahkota, 25200 Kuantan, Pahang, Malaysia; 2. National Fish Health Research Division, Fisheries Research Institute Batu Maung, Department of Fisheries Malaysia, 11960 Batu Maung, Penang, Malaysia; 3. Kulliyyah of Allied Health Science, International Islamic University Malaysia, Bandar Indera Mahkota, 25200 Kuantan, Pahang, Malaysia; 4. Laboratory of Aquatic Animal Health, Institute of Oceanography and Maritime Studies, International Islamic University Malaysia, Cherok Paloh, 26060 Kuantan, Pahang, Malaysia.
\end{abstract}

Corresponding author: Mohd. Firdaus-Nawi, e-mail: firdausn@iium.edu.my

Co-authors: MSMR: syafiq@dof.gov.my, AA: azila@dof.gov.my, RR: rimatulhana@dof.gov.my, NNM: nurnazifah@iium.edu.my, NR: norazsida@iium.edu.my

Received: 12-10-2021, Accepted: 21-01-2022, Published online: 26-02-2022

doi: www.doi.org/10.14202/vetworld.2022.465-482 How to cite this article: Ridzuan MSM, Abdullah A, Ramly R, Mansor NN, Ramli N, Firdaus-Nawi M (2022) Current status and advances of fish vaccines in Malaysia, Veterinary World, 15(2): 465-482.

\begin{abstract}
Fish diseases have a significant negative influence on the Malaysian aquaculture industry. Since the 1980s, the sector has grown in size, which has resulted in a rise in the prevalence of infectious outbreaks affecting both freshwater and marine cultured fish species. Demand for commercially available fish vaccinations is predicted to increase as infectious disease outbreaks continue to occur. In Malaysia, aquaculture vaccine research and development (R\&D) are still in its infancy, with most efforts concentrating on producing vaccines against bacterial infections, most notably streptococcosis, vibriosis, and motile Aeromonas septicemia. Despite several attempts, no homegrown vaccine has been effectively introduced into the manufacturing pipeline to date. At the moment, only three imported aquatic vaccines have received full permission, a far cry from the 314 and 60 vaccines licensed in the poultry and porcine industries, respectively. This review will describe recent findings regarding the development of aquaculture vaccines for certain fish species and diseases in Malaysia. In our opinion, $R \& D$ on fish vaccines is critical to the aquaculture industry's viability.
\end{abstract}

Keywords: aquaculture, fish, fish diseases, Malaysia, vaccine.

\section{Introduction}

Malaysia has recently developed aquaculture facilities for at least 49 marine and freshwater fish species. The most cultivated marine fish species are Asian seabass, snapper, and grouper. In contrast, the most cultured freshwater fish species are catfish, tilapia, and riverine catfish, with cumulative production of $121,553.75$ metric tonnes in 2020 [1]. Numerous culture systems, including ponds, cages, ex-mining pools, cement, and canvas tanks, have been adopted and practiced throughout Malaysia's coastal and freshwater locations. The fish farming business is developing with continued government backing and favorable response, resulting in intensification measures.

Unfortunately, the sector has also seen a variety of fish diseases in numerous fish species, resulting in massive economic losses and jeopardizing the company's long-term viability. Current solutions rely on a combination of good farm management and the use of commercially accessible antibiotics. The Malaysian government recently developed a national

Copyright: Ridzuan, et al. Open Access. This article is distributed under the terms of the Creative Commons Attribution 4.0 International License (http://creativecommons.org/licenses/ by/4.0/), which permits unrestricted use, distribution, and reproduction in any medium, provided you give appropriate credit to the original author(s) and the source, provide a link to the Creative Commons license, and indicate if changes were made. The Creative Commons Public Domain Dedication waiver (http:// creativecommons.org/publicdomain/zero/1.0/) applies to the data made available in this article, unless otherwise stated. action plan on antimicrobial resistance (MyAP-AMR) for the period of 2017-2021, which discourages the abuse of antibiotics in the food production industry. Furthermore, different efforts have been made to raise national awareness about AMR and antibiotics, expand the information and evidence base through surveillance and research, and optimize antimicrobial drug use [2]. Vaccination and alternative medicine are considered as a way out under these circumstances and have grown in popularity among local researchers, although acceptance among farmers remains questionable.

Several advancements and notable accomplishments have been made locally in the development of aquaculture vaccines against fish diseases. As a result, the purpose of this review is to offer an update on recent aquaculture vaccine development in Malaysia for major fish species and diseases. We genuinely hope that this analysis provides insight into the future potential for aquaculture fish vaccine development.

\section{General Overview of Recent Aquaculture Status in Malaysia}

The fisheries sector provides a significant portion of income for more than 106,000 local fishermen and farmers in Malaysia [1]. In addition, fisheries provide up to $12 \%$ of agriculture's gross domestic product (GDP) and $0.9 \%$ of the country's GDP [3]. While it may seem insignificant, the fisheries sector is vital in supplying food, jobs, nutrition, and a healthy 
lifestyle and supporting other downstream businesses. Malaysia's capture fisheries and aquaculture production totaled 1.6 million tonnes in 2020, a decrease of $2.36 \%$ from 2019 . Table- $1[1,3,4]$ compares the overall fisheries productivity in Malaysia from 2016 to 2020.

Malaysia's aquaculture sector is thriving with huge potential and ongoing government support to supply the rising demand for animal protein. Aquaculture is critical for boosting fish production, balancing demand on capture fisheries, and preventing wild fish overexploitation. Globally, aquaculture currently accounts for $46 \%$ of total fish production [5], with Asia accounting for more than $91 \%$ of worldwide aquaculture production [6]. In 2020, Malaysia had a total of 20,262 fish farmers. About 73.5\% (7,349 farmers) were engaged in freshwater aquaculture, while $16 \%$ (3,349 farmers) were engaged in brackish water aquaculture. In contrast, the remainder were in other sub-sectors classified as ornamental fish, aquatic plants, or seaweed. Malaysian freshwater aquaculture production totaled 97,209.74 tonnes worth RM 766 million in 2020, while brackish aquaculture production totaled 120,739.51 tonnes worth RM 2,289.39 million (Table-1).

On the other hand, seaweed production was estimated to reach $182,061.00$ tonnes of wet weight in 2020, accounting for RM 58.87 million of the wholesale value. Malaysia's aquaculture fish production system relies on conventional technologies such as ponds, ex-mining pools, cages, tanks, and pen culture (Table-2) [1]. The utilization of cutting-edge technology such as recirculating aquaculture systems is currently restricted to government hatcheries.

\section{Infectious Diseases of Fish in Malaysia}

Infectious diseases are any abnormalities caused by a wide range of microorganism infections. Bacteria and viruses are the main culprits in Malaysia's outbreaks of infectious illnesses in the aquaculture industry [7]. The most common bacterial diseases that affect cultured fish are Streptococcus agalactiae, Streptococcus iniae, Aeromonas hydrophila, and Vibrio alginolyticus [8-10]. Meanwhile, betanodavirus and iridovirus frequently affect cultured marine fish species, and recently the outbreaks of emerging diseases of tilapia lake virus (TiLV) were reported to affect the wild [11] and cultured tilapia [12]. These diseases have contributed substantial economic losses to the country, and actions must reduce the impact. Vaccination was considered the best control measure to protect the fish from infectious diseases by developing herd immunity [13]. A recent study by Standish et al. [14] proved the existence of herd immunity in aquatic animals, which played a crucial role in increasing the survival rate and disease resistance.

\section{Overview of Fish Vaccines Licensing in Malaysia}

The approval of any veterinary vaccine registration in Malaysia, including fish vaccines, is governed by the Department of Veterinary Services (DVS), Ministry of Agriculture and Food Industry, and is governed by the Animal Act 1953. As stated in Section 30(1) of the Animal Act 1953 (revised in 2006), the Director-General of DVS has the authority to provide a license authorizing the holder to possess live cultures or veterinary vaccinations and to administer them to animals or birds. In addition, Section 84(1) of the Animal Act 1953 (Amendment 2013) stated that no person should knowingly import or possess any living noxious insect, pest, or living germ, virus, or bacterial culture, that is harmful or dangerous to animals or birds without the Director-prior General's written permission. Therefore, the DVS as a regulatory agency controls the production, importation, distribution, sale, and use of veterinary vaccines for diagnosis, treatment, research, and disease prevention. The Technical Committee of Veterinary Product and National Veterinary Product Control Committee under DVS act as a licensing authority to register animal vaccines and other biologics. The licensure of new animal vaccines is subjected to a well-defined regulatory process. A general framework for the regulatory approval of veterinary vaccines is shown in Figure-1 [15].

At present, Malaysia has approved only three aquatic vaccines, which are shown in Table-3 [16]. These vaccines are inactivated and are meant to protect

Table-1: Fisheries and aquaculture production between 2016 and 2020 in Malaysia [1,3,4].

\begin{tabular}{lccccc}
\hline Year & $\mathbf{2 0 1 6}$ & $\mathbf{2 0 1 7}$ & $\mathbf{2 0 1 8}$ & $\mathbf{2 0 1 9}$ & $\mathbf{2 0 2 0}$ \\
\cline { 2 - 6 } & \multicolumn{5}{c}{ (Tonnes, live weight) } \\
\hline Production & & & & \\
Capture & 5847.97 & 5177.19 & 6089.08 & 5568.70 & 5625.14 \\
$\quad$ Inland & $1,574,447$ & $1,465,113$ & $1,452,862$ & $1,455,446$ & $1,383,299$ \\
$\quad$ Marine & $1,580,295.0$ & $1,470,290.2$ & $1,458,951.1$ & $1,461,014.7$ & $1,388,924.1$ \\
$\quad$ Total capture & & & & \\
Aquaculture & & & & & \\
$\quad$ Inland & $103,348.21$ & $102,596.83$ & $101,269.88$ & $104,601.56$ & $97,209.74$ \\
$\quad$ Marine & $98,049.9$ & $121,453.02$ & $116,112.08$ & $119,069.47$ & $120,739.51$ \\
$\quad$ Total aquaculture & $201,398.11$ & $224,049.85$ & $217,381.96$ & $223,671.03$ & $217,949.25$ \\
Total fisheries and aquaculture ${ }^{2}$ & $1,781,693.1$ & $1,694,340.0$ & $1,676,333.0$ & $1,684,685.7$ & $1,606,873.4$ \\
\hline
\end{tabular}

${ }^{1}$ Exclude production of seaweed. ${ }^{2}$ Total may not match due to rounding 
Table-2: Fractions of aquaculture production systems and areas adopted in Malaysia [1].

\begin{tabular}{|c|c|c|c|c|c|c|c|}
\hline $\begin{array}{l}\text { Production } \\
\text { system/area }\end{array}$ & Pond (Ha) & $\begin{array}{l}\text { Ex-mining } \\
\text { pool }(\mathrm{Ha})\end{array}$ & $\begin{array}{c}\text { Cages } \\
\left(\mathrm{m}^{2} \times 10^{3}\right)\end{array}$ & $\begin{array}{c}\operatorname{Tank}^{1} \\
\left(\mathrm{~m}^{2} \times 10^{3}\right)\end{array}$ & $\begin{array}{c}\text { Pen culture } \\
(\mathrm{Ha})\end{array}$ & $\begin{array}{c}\text { Molluscs } \\
\text { culture }^{2}(\mathrm{Ha})\end{array}$ & $\begin{array}{c}\text { Seaweed } \\
\text { culture }(\mathrm{Ha})\end{array}$ \\
\hline reshwater & 3725.29 & 3033.00 & 0 & 99 & 8.00 & - & 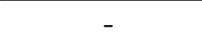 \\
\hline Brackish water & 7511.00 & - & 2304.47 & 0 & $392,368.00$ & 9714.00 & 9828.00 \\
\hline Total & $11,236.29$ & 3033.00 & 2854.47 & 656.99 & $392,376.00$ & 9714.00 & 9828.00 \\
\hline
\end{tabular}

${ }^{1}$ Include cement and canvas tank. ${ }^{2}$ Include cockle (bottom culture), mussel, and oyster (raft culture)

Table-3: List of approved aquatic vaccines in Malaysia [16].

\begin{tabular}{|c|c|c|c|c|c|c|c|}
\hline $\begin{array}{l}\text { Trade } \\
\text { name }\end{array}$ & $\begin{array}{l}\text { Causative } \\
\text { agent }\end{array}$ & Manufacturer & $\begin{array}{l}\text { Nature of } \\
\text { vaccine }\end{array}$ & $\begin{array}{l}\text { Recommended } \\
\text { species }\end{array}$ & $\begin{array}{l}\text { Delivery } \\
\text { methods }{ }^{1}\end{array}$ & $\begin{array}{l}\text { Dose and } \\
\text { recommended } \\
\text { fish size }\end{array}$ & $\begin{array}{l}\text { Further } \\
\text { information }\end{array}$ \\
\hline $\begin{array}{l}\text { AquaVac } \\
\text { Strep SI }\end{array}$ & S. iniae & $\begin{array}{l}\text { Intervet, } \\
\text { Holland }\end{array}$ & Killed & $\begin{array}{l}\text { Tilapia; Asian } \\
\text { seabass; Other } \\
\text { susceptible fish } \\
\text { species }\end{array}$ & IP; IMM & $\begin{array}{l}\text { Injection: } \\
0.1 \mathrm{~mL} / \text { fish; for fish } \\
20 \mathrm{~g} \text { or above } \\
\text { Immersion: } 1 \mathrm{~L} \text { of } \\
\text { vaccine and } 9 \mathrm{~L} \text { of } \\
\text { seawater; for fish } \\
3 \mathrm{~g} \text { and above }\end{array}$ & $\begin{array}{l}\text { www. } \\
\text { aquavac-vaccines. } \\
\text { com/ }\end{array}$ \\
\hline $\begin{array}{l}\text { AquaVac } \\
\text { IridoV }\end{array}$ & Iridovirus & $\begin{array}{l}\text { Intervet, } \\
\text { Holland }\end{array}$ & Killed & $\begin{array}{l}\text { Asian seabass; } \\
\text { Grouper; } \\
\text { Pompano; } \\
\text { Japanese } \\
\text { yellowtail }\end{array}$ & IP & $\begin{array}{l}0.05 \mathrm{~mL} / \text { fish; for } \\
\text { fish } 5 \mathrm{~g} \text { or above }\end{array}$ & $\begin{array}{l}\text { www. } \\
\text { aquavac-vaccines. } \\
\text { com/ }\end{array}$ \\
\hline $\begin{array}{l}\text { Vibri- } \\
\text { Fishvax }\end{array}$ & $\begin{array}{l}\text { Vibrio } \\
\text { anguillarum }\end{array}$ & $\begin{array}{l}\text { Fatro S.p.A, } \\
\text { Italy }\end{array}$ & Killed & $\begin{array}{l}\text { Trout; Salmon; } \\
\text { Seabass; } \\
\text { Seabream }\end{array}$ & IP; IMM & $\begin{array}{l}\text { Injection: } \\
0.1 \mathrm{~mL} / \mathrm{fish} \text {; for fish } \\
50 \mathrm{~g} \text { or above } \\
\text { Immersion: dip } \\
7.5-10 \mathrm{~kg} \text { of fish per } \\
1 \mathrm{~L} \text { of vaccine ( } 1: 10 \\
\text { ratio); fish between } \\
1 \text { and } 8 \mathrm{~g}\end{array}$ & www.fatro.it \\
\hline
\end{tabular}

${ }^{1} \mathrm{IP}=$ Intraperitoneal injection, IMM=Immersion

against streptococcosis, vibriosis, and iridoviral disease. Notably, other vaccine forms, such as recombinant, DNA, or live-attenuated vaccinations, have not been licensed for aquaculture use in Malaysia.

\section{Overview of Recent Research and Development (R\&D) of the Fish Vaccine in Malaysia}

Malaysian research on fish vaccines predates 1979 and has lagged much behind other countries. Initially, this project was sparked by the rapid expansion of marine fish mariculture, including sea bass (Lates calcarifer), grouper (Epinephelus coioides), and golden snapper (Lutjanus johni), which began in 1973 and accelerated in the 1980s. Fingerlings or juveniles were brought in large quantities from neighboring countries such as Chinese Taipei, Indonesia, and Thailand to deal with vast demand and concentration [17]. Due to the increased intensity of aquaculture, an episode of disease outbreak is frequently experienced during the initial stocking and growout stage. Throughout a 1-year survey conducted by Chuah [18], it was discovered that groupers were primarily linked to viral diseases $(50 \%)$, with bacterial infections accounting for $47 \%$ and cryptocaryoniasis accounting for the remaining 3\%. Based on the culturists' descriptions of the discoloration (blackening) of the fish body without other external symptoms, it was suspected that the virus-associated disease was iridoviral infection, whereas the bacterial-associated disease of Vibrio spp. and Flexibacter spp. caused ulceration or rotting of the groupers' fins and tail.

One of the earliest studies on the fish vaccine in Malaysia was recorded in the late seventies. See-Yong et al. [19] explored the root cause of red boil disease in estuary grouper (Epinephelus salmoides) with the possibility of vaccination control. Their study found that Vibrio parahaemolyticus is the cause of disease based on colony morphology on selective Thiosulfatecitrate-bile salts-sucrose media and pathogenicity test. Unfortunately, they were unable to develop effective vaccines against $V$. parahaemolyticus utilizing several means of inactivation, including heat-killed and formalin-killed, with and without adjuvant. When challenged 1 week after immunization, all the vaccines failed to protect the fish, with $60-70 \%$ mortality rates. However, the absence of protection was most likely caused by the bacterium being challenged before the immunity developed.

Another mass vaccination trial was conducted in Malaysia in the late 1990s, with special permission granted to a government research institute, the National Fish Health Research Centre (NaFisH), Fisheries Research Institute Batu Maung, Penang, to conduct a field vaccination trial using Alpharma vaccine on Lutjanus argentimaculatus against vibriosis 


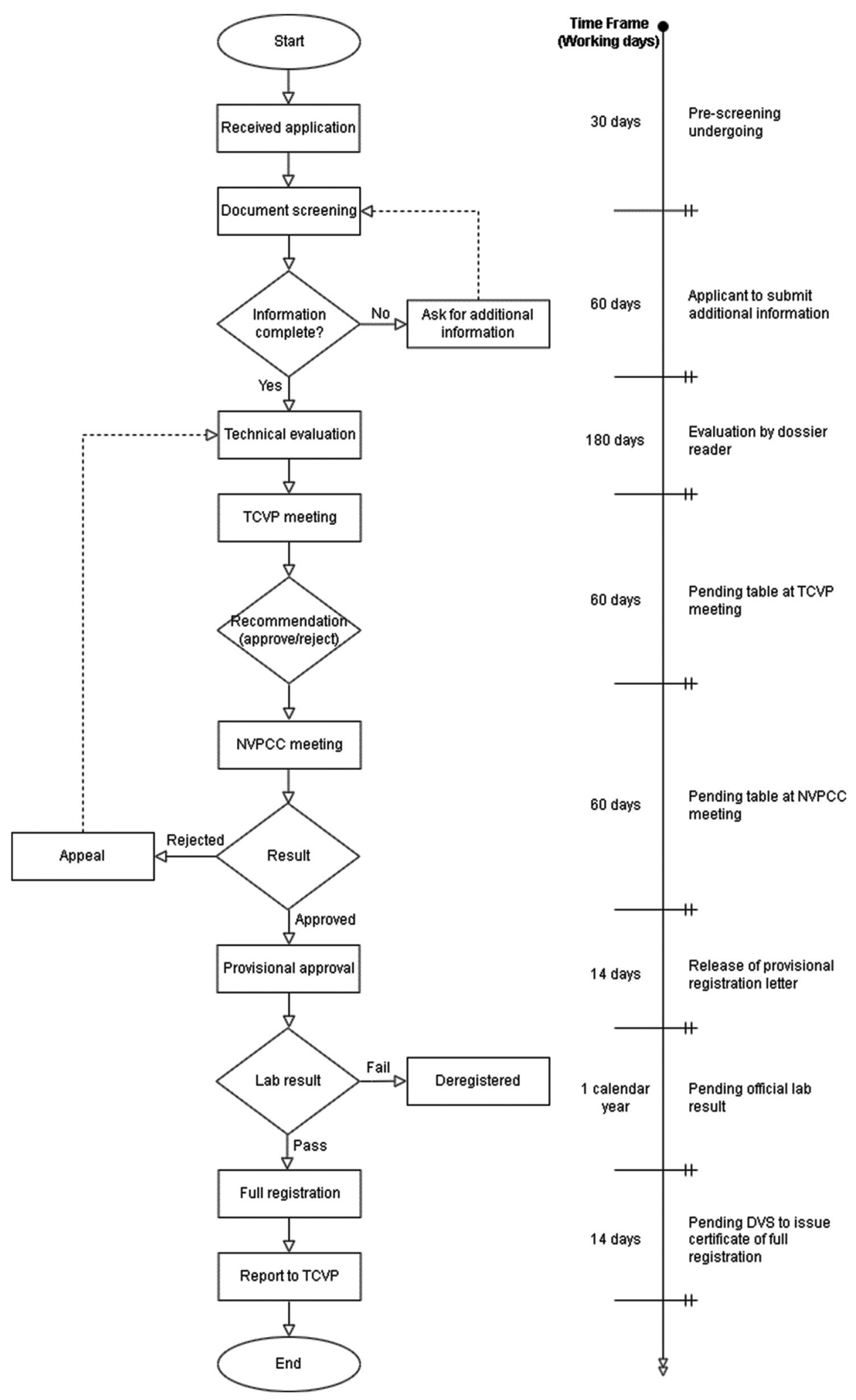

Figure-1: Flow chart and time frame of veterinary vaccines registration in Malaysia [15].

[20]. A total of 19,000 fish were vaccinated in-house at the hatchery before being sent to Langkawi Island for cage culture. Unfortunately, between 24 and $48 \mathrm{~h}$ after immunization aberrant mortality $(100 \%)$ was seen, along with bulging of the ocular membrane on the dead fish. As a result, a replicated study on a laboratory scale was done to ascertain any predisposing conditions that may have contributed to the situation.
Initially, it was suspected that the vaccine or its storage conditions were to blame. However, the vaccine had no detrimental effects, and no abnormalities were observed during the laboratory testing. In addition, the physical and behavioral alterations observed within 24-48 h post-vaccination were missing after 2 weeks of monitoring, as described in the field trial. As a result, they hypothesized that prior catastrophic 
incidents could have been caused by handling stress and a high stocking density in the holding net prior to injection. Since then, local researchers have made enormous strides, as seen by an increase in the volume of study on epidemiology, pathogenicity, vaccine development, and other relevant topics. This section will discuss the state of fish vaccine $\mathrm{R} \& \mathrm{D}$ in Malaysia for specific fish species and diseases.

\section{Streptococcosis vaccine}

Streptococcosis is one of the most extensive vaccines studied in Malaysia due to the aggressive series of outbreaks affecting tilapia culture in Malaysia, dating back to 1997 [21,22]. The disease is a bacterial infection caused by Streptococcus species. S. agalactiae and $S$. iniae are the major species affecting tilapia aquaculture production worldwide, including Malaysia [8,23,24]. The clinical symptoms and signs of streptococcosis infected fish include exophthalmia or pop-eye, corneal opacity, hemorrhage at the gill and body surface, inflammation and soft brain, ascites, and display erratic swimming behavior [24,25]. Histological examination of hybrid tilapia naturally infected by $S$. agalactiae revealed marked congestion and infiltration of inflammatory cells in the eye, brain, kidney, liver, and spleen [26].

The first reported case of streptococcosis in Malaysia was documented in the late 1990s at Pahang River, Pahang affecting tilapia weighing between 300 and $400 \mathrm{~g}$ and resulting in $60 \%$ mortality of cultured red hybrid tilapia. In 2000, a series of disease outbreaks were recorded in Kenyir Lake, Terengganu, and Pergau Lake, Kelantan, resulting in approximately $50 \%$ mortality of cultured tilapia $[21,22,27]$. Repeated cases were encountered in Aquaculture Industrial Zone at Kenyir Lake [28] and Temerloh, Pahang [26], causing mass mortality of cage-cultured red hybrid tilapia. The outbreaks commonly occur during hot and dry months and are correlated with high water temperature $\left(\geq 29^{\circ} \mathrm{C}\right)[29]$. A similar finding by Pei-Chih et al. [23] reported that water temperature above $27^{\circ} \mathrm{C}$ was predisposed tilapia to streptococcosis infection in Taiwan. Furthermore, in an experimental trial, Rodkhum et al. [30] showed Nile tilapia that were exposed to a high water temperature of $30^{\circ} \mathrm{C}$ and $33^{\circ} \mathrm{C}$, after immersion challenged with $S$. agalactiae, resulted in high cumulated mortality compared to the tilapia maintained at $25^{\circ} \mathrm{C}$ where most of the fish survived without any clinical signs.

More recently, Siti Hawa et al. [8] reported that $S$. iniae was responsible for some of the cases in cultured red tilapia since 2006. Currently, reported disease cases are widespread, covering all over Peninsular Malaysia. An extensive review of the status of the disease in Malaysia was previously described by ZamriSaad et al. [31]. Although the evidence of $S$. agalactiae serotype Ia was recently discovered [32], local isolates predominantly corresponded to Serotype III and Biotype 1 [33]. In Malaysia, infection by $S$. agalactiae has also been reported in golden pompano, Trachinotus blochii [34].

An epidemic of streptococcosis outbreaks was also documented worldwide. For instance, in his recent article, Pei-Chih et al. [23] reported that the clinical cases of Oreochromis spp. in Taiwan were predominated by bacterial infection, where streptococcosis accounted for $53.7 \%$ of the cases, and the infection rate was recorded at $29.5 \%$. Meanwhile, in China, sporadic cases of streptococcosis involving $S$. agalactiae have been reported in several provinces of Guangdong, Guangxi, Hainan, and Fujian, which led to massive cumulative mortality and economic losses [35]. It is worth noting that these four central tilapia-producing provinces accounted for $40 \%$ of global tilapia production. In addition, between 2016 and 2017, six disease outbreaks were reported in Brazil, affecting Nile tilapia with total death rates of $25-35 \%$ [36]. Further investigation revealed that the primary etiological agent was $S$. agalactiae Serotype III. Recently, the disease was reported to have caused enormous losses in Thailand's freshwater farmed seabass, with a cumulative mortality rate of $35-65 \%$ [37]. Interestingly, Al-Harbi [38] previously reported evidence of non-hemolytic Group B $S$. agalactiae infection resulting in typical streptococcal clinical symptoms, culminating in acute or chronic infections of cultured tilapia in Saudi Arabia. Streptococci-related global losses were previously estimated at USD250 million in $2008[39,40]$.

Hence, it is now realized that these bacteria pose a considerable threat to tilapia farming, so producing an effective vaccine is rather urgent. In Malaysia, several types of vaccines, such as inactivated, recombinant, and live attenuated vaccines; Different routes of vaccination, such as oral, injectable, or immersion, were extensively explored by local researchers against S. agalactiae and S. iniae (Table-4) [41-59].

\section{Development of a vaccine against $S$. agalactiae}

Rather than developing an injectable or immersion vaccine against streptococcosis, significant resources were expended in developing an oral vaccine. The oral route becomes the most preferred route because $80 \%$ of the local tilapia culturists are small-scale operators. Utilizing injectable or immersion courses necessitated additional infrastructure and labor, a massive endeavor that added to the load on these farmers. Oral vaccines, which are generally prepared by infusing the antigen into feed, are suited for mass vaccination of fish of all sizes and ages. Oral administration is the most appealing way since it is straightforward, less stressful for fish, and provides a more flexible approach to vaccination regime formulation [60].

Despite offering attractive features, it is essential to note that oral vaccination also has its limitations and usually provides a shorter duration of protection when compared to injection immunization. Furthermore, 
Table-4: Different experimental approaches and trials in the development of fish vaccine in Malaysia.

\begin{tabular}{|c|c|c|c|c|c|c|}
\hline $\begin{array}{l}\text { Name of } \\
\text { pathogen (s) }\end{array}$ & $\begin{array}{l}\text { Type of } \\
\text { vaccine }\end{array}$ & $\begin{array}{l}\text { Vaccination } \\
\text { route }\end{array}$ & $\begin{array}{l}\text { Stage } \\
\text { of } \\
\text { trial }\end{array}$ & $\begin{array}{l}\text { Fish } \\
\text { species }\end{array}$ & Finding & Reference \\
\hline S. agalactiae & Inactivated & Oral & $\begin{array}{l}\text { Lab } \\
\text { trial }\end{array}$ & $\begin{array}{l}\text { Red } \\
\text { tilapia }\end{array}$ & $\begin{array}{l}\text { - Adjuvanted vaccine group resulted } \\
\text { in the highest survival rate (100\%), } \\
\text { followed by non-adjuvanted group } \\
(50 \%) \text { and control (12.5\%) } \\
\text { - Adjuvanted vaccine group resulted } \\
\text { in significant higher IgM level, } \\
\text { increase in the size of gut-associated } \\
\text { lymphoid tissue and number of } \\
\text { lymphocytes }\end{array}$ & [41] \\
\hline S. agalactiae & Inactivated & Oral & $\begin{array}{l}\text { Lab } \\
\text { trial }\end{array}$ & $\begin{array}{l}\text { Red } \\
\text { tilapia }\end{array}$ & $\begin{array}{l}\text { - Double booster group resulted in } \\
\text { highest survival }(70 \%) \text {, followed } \\
\text { by single booster group ( } 45 \%) \text { and } \\
\text { control }(0 \%) \\
\text { - Following first administration and } \\
\text { booster dose, both vaccinated groups } \\
\text { showed significantly higher serum IgM } \\
\text { levels and reached the peak at week-3 } \\
\text { before declining. Following the second } \\
\text { booster in week } 6 \text {, the antibody level } \\
\text { significantly increased again and } \\
\text { remained high until week-12 }\end{array}$ & {$[42]$} \\
\hline S. agalactiae & Inactivated & Oral & $\begin{array}{l}\text { Field } \\
\text { trial }\end{array}$ & $\begin{array}{l}\text { Red } \\
\text { tilapia }\end{array}$ & $\begin{array}{l}\text { - The survival rate was } 75 \% \text { for the } \\
\text { double booster group, } 65 \% \text { for single } \\
\text { booster and } 45 \% \text { for unvaccinated } \\
\text { - Following vaccination, both } \\
\text { vaccinated groups showed a } \\
\text { significant increase in the antibody } \\
\text { level that reached the peak at week- } 4 \\
\text { but gradually declined thereafter. } \\
\text { However, following another booster at } \\
\text { week-6 (double booster group), the } \\
\text { antibody level showed a significant } \\
\text { increase and remained high until the } \\
\text { end of the study period }\end{array}$ & [43] \\
\hline S. agalactiae & Recombinant & Oral & $\begin{array}{l}\text { Lab } \\
\text { trial }\end{array}$ & $\begin{array}{l}\text { Red } \\
\text { tilapia }\end{array}$ & $\begin{array}{l}\text { - The survival rate was } 70 \% \text { for } \\
\text { recombinant vaccine } \\
\text { - Feed-based recombinant vaccine } \\
\text { developed a strong and significantly } \\
\text { higher IgM antibody response in } \\
\text { serum, mucus, and gut lavage fluid }\end{array}$ & {$[44]$} \\
\hline S. agalactiae & Recombinant & Oral & $\begin{array}{l}\text { Field } \\
\text { trial }\end{array}$ & $\begin{array}{l}\text { Red } \\
\text { tilapia }\end{array}$ & $\begin{array}{l}\text { - No outbreak of streptococcosis was } \\
\text { recorded during the study period } \\
\text { - The IgM antibody level in serum, } \\
\text { mucus, and gut lavage was } \\
\text { significantly higher in vaccinated } \\
\text { groups. Aggregation of lymphocytes } \\
\text { and development of GALT was } \\
\text { observed in vaccinated fish }\end{array}$ & {$[45]$} \\
\hline S. agalactiae & Inactivated & Oral & $\begin{array}{l}\text { Lab } \\
\text { trial }\end{array}$ & $\begin{array}{l}\text { Red } \\
\text { tilapia }\end{array}$ & $\begin{array}{l}\text { - The highest survival rate (70\%) was } \\
\text { recorded in the vaccinated group } \\
\text { using } 10 \% \text { palm oil, followed by } 7 \% \\
\text { Freund's incomplete adjuvant ( } 45 \%) \\
\text { - Both vaccinated groups displayed } \\
\text { higher antibody response with a } \\
\text { similar pattern }\end{array}$ & {$[46]$} \\
\hline S. agalactiae & Inactivated & Spray immersion & $\begin{array}{l}\text { Lab } \\
\text { trial }\end{array}$ & $\begin{array}{l}\text { Red } \\
\text { tilapia }\end{array}$ & $\begin{array}{l}\text { - A higher percentage of survival was } \\
\text { noted for fish challenged through } \\
\text { immersion ( } 80 \%) \text { compared with an } \\
\text { intraperitoneal injection ( } 70 \%) \\
\text { - Serum and mucus antibodies } \\
\text { correspond to each booster. Both } \\
\text { antibody levels remained high after } \\
\text { the last booster until the end of the } \\
\text { 8-week study period }\end{array}$ & [47] \\
\hline
\end{tabular}


Table-4: (Continued).

\begin{tabular}{|c|c|c|c|c|c|c|}
\hline $\begin{array}{l}\text { Name of } \\
\text { pathogen (s) }\end{array}$ & $\begin{array}{l}\text { Type of } \\
\text { vaccine }\end{array}$ & $\begin{array}{l}\text { Vaccination } \\
\text { route }\end{array}$ & $\begin{array}{l}\text { Stage } \\
\text { of } \\
\text { trial }\end{array}$ & $\begin{array}{l}\text { Fish } \\
\text { species }\end{array}$ & Finding & Reference \\
\hline S. agalactiae & $\begin{array}{l}\text { Inactivated } \\
\text { and biofilm }\end{array}$ & Oral & $\begin{array}{l}\text { Lab } \\
\text { trial }\end{array}$ & $\begin{array}{l}\text { Red } \\
\text { tilapia }\end{array}$ & $\begin{array}{l}\text { - Fish vaccinated with biofilm vaccine } \\
\text { showed the highest survival } \\
\text { percentage }(87 \%) \text {, followed by fish } \\
\text { fed with whole-cell vaccine (57\%) } \\
\text { - The serum, mucus, and gut lavage } \\
\text { antibody level of fish vaccinated with } \\
\text { biofilm vaccine was significantly higher } \\
\text { than other groups }\end{array}$ & {$[48]$} \\
\hline S. agalactiae & $\begin{array}{l}\text { Live } \\
\text { attenuated }\end{array}$ & Oral & $\begin{array}{l}\text { Lab } \\
\text { trial }\end{array}$ & $\begin{array}{l}\text { Red } \\
\text { tilapia }\end{array}$ & $\begin{array}{l}\text { - The RPS of fish vaccinated with } \\
\text { live attenuated vaccine was } 82 \% \\
\text { compared to } 2.5 \% \text { in control } \\
\text { - After the first and booster dose, the } \\
\text { serum IgM levels increased significantly } \\
\text { and reached the peak on the week-5 }\end{array}$ & [49] \\
\hline S. iniae & Inactivated & Oral & $\begin{array}{l}\text { Lab } \\
\text { trial }\end{array}$ & $\begin{array}{l}\text { Red } \\
\text { tilapia }\end{array}$ & $\begin{array}{l}\text { - No efficacy data provided } \\
\text { - Group of fish vaccinated for three and } \\
\text { five consecutive days with booster } \\
\text { on day-14 and day- } 21 \text { recorded the } \\
\text { lowest antigen positivity } \\
\text { - Group of fish vaccinated for five } \\
\text { consecutive days with booster on } \\
\text { day- } 14 \text { and day- } 21 \text { showed the } \\
\text { stimulation and irregular projection of } \\
\text { M-cells with variable morphology and } \\
\text { antigen distribution pattern }\end{array}$ & {$[50]$} \\
\hline S. iniae & Inactivated & Oral & $\begin{array}{l}\text { Lab } \\
\text { trial }\end{array}$ & $\begin{array}{l}\text { Red } \\
\text { tilapia }\end{array}$ & $\begin{array}{l}\text { - Groups of fish vaccinated continuously } \\
\text { for } 9 \text { days with booster on day-14 and } \\
\text { day- } 21 \text { recorded the highest survival } \\
\text { of } 70 \% \\
\text { - All vaccinated groups showed a } \\
\text { significant increase in IgM levels in } \\
\text { serum, mucus, and gut lavage }\end{array}$ & [51] \\
\hline $\begin{array}{l}\text { Aeromonas } \\
\text { hydrophila }\end{array}$ & Recombinant & Intra-peritoneal & $\begin{array}{l}\text { Lab } \\
\text { trial }\end{array}$ & $\begin{array}{l}\text { African } \\
\text { catfish }\end{array}$ & $\begin{array}{l}\text { - The RPS of all vaccinated groups was } \\
\text { significantly higher }(100 \%) \text { compared } \\
\text { to placebo }(29.42 \%)\end{array}$ & {$[52]$} \\
\hline $\begin{array}{l}\text { S. iniae; } \\
\text { A. hydrophila }\end{array}$ & $\begin{array}{l}\text { Inactivated; } \\
\text { bivalent }\end{array}$ & Oral & $\begin{array}{l}\text { Lab } \\
\text { trial }\end{array}$ & $\begin{array}{l}\text { Red } \\
\text { tilapia }\end{array}$ & $\begin{array}{l}\text { - Group of fish vaccinated by bivalent } \\
\text { vaccine incorporated in feed achieved } \\
\text { the highest RPS of } 80 \%, 77 \% \text { and } 77 \% \\
\text { following challenged against S. iniae, } \\
\text { A. hydrophila, and co-infection of both } \\
\text { bacteria, respectively } \\
\text { - Lysozyme and phagocytic activity } \\
\text { and, serum antibody was significantly } \\
\text { higher against S. iniae and } \\
\text { A. hydrophila in vaccinated groups in } \\
\text { the pre and post-challenged }\end{array}$ & [53] \\
\hline $\begin{array}{l}\text { V. harveyi; } \\
\text { S. agalactiae; } \\
\text { A. hydrophila }\end{array}$ & $\begin{array}{l}\text { Inactivated; } \\
\text { Polyvalent }\end{array}$ & Oral & $\begin{array}{l}\text { Lab } \\
\text { trial }\end{array}$ & $\begin{array}{l}\text { Asian } \\
\text { seabass }\end{array}$ & $\begin{array}{l}\text { - The vaccine provided a RPS of } 75 \% \text {, } \\
80 \% \text {, and } 80 \% \text { after challenge } \\
\text { with V. harveyi, A. hydrophila, and } \\
\text { S. agalactiae, respectively } \\
\text { - The serum antibody and lysozyme } \\
\text { remained significantly higher } \\
\text { at the end of } 6 \text { weeks trial. The } \\
\text { immune-related gene, dendritic } \\
\text { cells, Chemokine ligand } 4 \text {, and major } \\
\text { histocompatibility complex class I } \\
\text { were highly expression after the fish } \\
\text { were vaccinated with the oral vaccine }\end{array}$ & [54] \\
\hline V. harveyi & $\begin{array}{l}\text { Live } \\
\text { attenuated }\end{array}$ & Intra-peritoneal & $\begin{array}{l}\text { Lab } \\
\text { trial }\end{array}$ & $\begin{array}{l}\text { Tiger } \\
\text { grouper }\end{array}$ & $\begin{array}{l}\text { - The RPS of the vaccinated group was } \\
\text { calculated at } 52 \% \\
\text { - Vaccinated fish displayed upregulation } \\
\text { of autophagosome pathway, the } \\
\text { coagulation and complement cascade } \\
\text { pathways, and antigen processing and } \\
\text { presentation pathways }\end{array}$ & {$[55]$} \\
\hline
\end{tabular}


Table-4: (Continued).

\begin{tabular}{|c|c|c|c|c|c|c|}
\hline $\begin{array}{l}\text { Name of } \\
\text { pathogen (s) }\end{array}$ & $\begin{array}{l}\text { Type of } \\
\text { vaccine }\end{array}$ & $\begin{array}{l}\text { Vaccination } \\
\text { route }\end{array}$ & $\begin{array}{l}\text { Stage } \\
\text { of } \\
\text { trial }\end{array}$ & $\begin{array}{l}\text { Fish } \\
\text { species }\end{array}$ & Finding & Reference \\
\hline V. harveyi & $\begin{array}{l}\text { Live } \\
\text { attenuated }\end{array}$ & Bath immersion & $\begin{array}{l}\text { Lab } \\
\text { trial }\end{array}$ & $\begin{array}{l}\text { Asian } \\
\text { seabass }\end{array}$ & $\begin{array}{l}\text { - Fish vaccinated with live attenuated } \\
\text { vaccine resulted in a significantly high } \\
\text { rate of survival ( } 68 \% \text { ) after being } \\
\text { challenged with the wild type strain } \\
\text { - Increase expressions of the Chemokine } \\
\text { ligand } 4 \text { and major histocompatibility } \\
\text { complex I genes in the skin and liver of } \\
\text { the vaccinated fish }\end{array}$ & {$[56]$} \\
\hline V. harveyi & Inactivated & Intra-peritoneal & $\begin{array}{l}\text { Lab } \\
\text { trial }\end{array}$ & $\begin{array}{l}\text { Marine } \\
\text { red } \\
\text { tilapia }\end{array}$ & $\begin{array}{l}\text { - Vaccinated group resulted in a } \\
\text { significantly higher rate of survival } \\
(87 \%) \\
\text { - The IgM antibody titer and lysozyme } \\
\text { of vaccinated fish were significantly } \\
\text { higher throughout the experiment }\end{array}$ & {$[55]$} \\
\hline V. alginolyticus & Recombinant & Intra-peritoneal & $\begin{array}{l}\text { Lab } \\
\text { trial }\end{array}$ & $\begin{array}{l}\text { Hybrid } \\
\text { grouper }\end{array}$ & $\begin{array}{l}\text { - The RPS for the rOmpK vaccinated } \\
\text { group was } 100 \% \text {, followed by } 63 \% \text { for } \\
\text { the rOmpW group } \\
\text { - Both rOmpK and rOmpW vaccinated } \\
\text { groups displayed an increasing pattern } \\
\text { of serum IgM following vaccinations } \\
\text { - The IgM against rOmpK showed } \\
\text { significantly higher values than } \\
\text { rOmpW at the challenge on day } 28 \\
\text { post-vaccination }\end{array}$ & {$[57,58]$} \\
\hline $\begin{array}{l}\text { V. alginolyticus; } \\
\text { V. harveyi }\end{array}$ & $\begin{array}{l}\text { Recombinant; } \\
\text { bivalent }\end{array}$ & Intra-peritoneal & $\begin{array}{l}\text { Lab } \\
\text { trial }\end{array}$ & $\begin{array}{l}\text { Asian } \\
\text { seabass }\end{array}$ & $\begin{array}{l}\text { - Fish vaccinated with r-OmpK had a } \\
90 \% \text { survival rate against } V \text {. harveyi } \\
\text { and } 100 \% \text { against V. alginolyticus and } \\
\text { Vibrio parahaemolyticus } \\
\text { - The blood and gut lavage antibody } \\
\text { of fish vaccinated with r-OmpK were } \\
\text { increased significantly and TLR2, } \\
\text { MyD88, and MHCI genes were } \\
\text { upregulation in the kidney and intestinal } \\
\text { tissues of r-OmpK vaccinated fish }\end{array}$ & [59] \\
\hline
\end{tabular}

S. iniae=Streptococcus iniae, A. hydrophila=Aeromonas hydrophila, V. harveyi=Vibrio harveyi, A. hydrophila=Aeromonas hydrophila, S. agalactiae=Streptococcus agalactiae, V. alginolyticus=Vibrio alginolyticus, RPS=Relative percent survival

oral administration makes it impossible to determine the exact dose of antigen each fish takes and occasionally results in inconsistent responses because of the fish's harsh acidic stomach contact. As a result, the antigen is susceptible to being destroyed prior to rousing the gut-associated lymphoid tissues (GALTs) and priming immune cells [61]. Therefore, conjugation with a large immunogenic carrier called an adjuvant is crucial to permit a prolonged antigen release [62]. Different types of adjuvants have been tested for fish vaccines, such as alginate microspheres encapsulated [63], nanoparticle [64], Freund's incomplete adjuvant (FIA) [65], and polysaccharides [66], with promising results.

The effect of oral vaccination of killed wholecell $S$. agalactiae vaccine on stimulating GALTs in tilapia was previously investigated by Firdaus-Nawi et al. [67]. Their study discovered that once-weekly vaccination exposure was adequate to stimulate the GALT, but repeated doses elicited stronger responses. Moreover, the size of GALT and the number of aggregated lymphoid cells in tilapia's gastrointestinal tract were much greater than in unvaccinated fish. Their finding provides an early indication that oral exposures to the killed antigen incorporated in feed could be used in a vaccination procedure to protect tilapia from $S$. agalactiae infection.

The protective capacity of locally produced oil adjuvanted oral vaccine against streptococcosis in tilapia was subsequently reported [41]. They investigated the effect of immunological response between fish fed with adjuvanted feed-based vaccine, feedbased vaccine (without adjuvant), and unvaccinated groups, following a vaccination regime in a laboratory vaccination trial. They found that following the vaccination regime, the antibody level (immunoglobulin $\mathrm{M}$ $[\operatorname{IgM}]$ ) in serum, mucus, and gut lavage fluid of both vaccinated groups was significantly higher $(p<0.05)$ as early as 1-week post-immunization, and the increasing pattern was constantly observed till the end of the experiment of week 7. Moreover, the antibody level produced in fish fed with the adjuvanted feedbased vaccine was also significantly higher $(\mathrm{p}<0.05)$ than fish provided with the feed-based vaccine (without adjuvant). Intraperitoneal challenge against high concentration of live virulent $S$. agalactiae resulted in $100 \%$ survival in fish fed with adjuvanted vaccine group, while $50 \%$ and $12.5 \%$ survival of fish fed with 
the feed-based vaccine (without adjuvant) and control group, respectively. Another laboratory trial of a feed-based vaccine against $S$. agalactiae in red tilapia showed that a double booster vaccination regime (weeks 0,2 , and 6 ) at $4 \%$ of body weight successfully provided a consistently high level of serum IgM antibody for 4 months [42]. Following the excellent results in the laboratory setting, a field trial was undertaken and tested in an endemic farm [43]. A similar vaccination regime was employed in the field study and resulted in $75 \%$ survival of the vaccinated group compared to $45 \%$ survival in the unvaccinated group. Interestingly, the author and coworkers demonstrated a comparable serum antibody (IgM) pattern between laboratory and field trials.

A more advanced approach in antigen preparation of $S$. agalactiae involving recombinant DNA technology such as insertion of genetic materials that encode antigen into an expressing vector was also explored by local researchers. As such, Nur-Nazifah et al. [44] previously reported that an adequate protective capacity of an inactivated recombinant vaccine expresses the cell wall surface anchor family protein of $S$. agalactiae in tilapia, following high dose challenge in a heat-stress environment with a record of $70 \%$ survival. Again, an elevated antibody level in blood serum, body mucus, and gut lavage fluid was significantly higher $(\mathrm{p}<0.05)$ and correlated with protection rate. Thus, they believed that the application of appropriate adjuvant could tremendously enhance vaccine efficacy. This finding has led to the vaccination field trials carried out in Kenyir Lake, Terengganu, and East Coast of Malaysia [45]. The same recombinant vaccine that expresses the cell wall surface anchor family protein of $S$. agalactiae in the presence of FIA was used and administered orally during both rainy and dry seasons. In both seasons, the vaccinated group showed elevated levels of serum, mucus, and gut lavage fluid antibody $(\operatorname{IgM})(\mathrm{p}<0.05)$ as early as $2^{\text {nd }}$ month post-vaccination and continued to increase after booster (given at month-2) until the end of the trial at $4^{\text {th }}$ month. Stimulation of the GALT was also observed after the $1^{\text {st }}$ month of antigen exposure in the intestine as individual cells or small aggregations in both the epithelium and lamina propria. Better stimulation of GALT was found at the $4^{\text {th }}$ month correlated with repeated exposure of antigen of a booster dose.

More recently, Sa'aidatun Asyikin et al. [46] reported the utilization of palm oil as an adjuvant substitute in $S$. agalactiae oral vaccine with promising results. Palm oil is unique among vegetable oils because of its high saturated fatty acid content at the 2-position of its triglycerides and is an excellent source of cheaper adjuvant alternatives due to the vitamin E and saponin content. Both have previously been shown to enhance cell-mediated immunity and antibody production $[46,68]$. In addition, another work by Mufti et al. [69] showed that a mixture of palm and coconut oil adjuvants in a duck pasteurellosis nanovaccine was physicochemically stable following a 6-month pretreatment period at 4,25 , and $40^{\circ} \mathrm{C}$.

Another route of administration of vaccine against the disease was also extensively explored. For example, Noraini et al. [47] reported the potential use of spray administration of the formalin-killed S. agalactiae vaccine earlier. Antigen administration through spray could theoretically transfer antigens to mucosal tissues, such as the skin, gill, and nasal, where they can activate innate and adaptive immune responses in the fish [70]. The authors evaluated the frequency effect of spray vaccination on fish that received a single spray, fish that received a daily spray for 5 consecutive days, and fish that were not vaccinated. In the $2^{\text {nd }}$ and $4^{\text {th }}$ weeks, each group received two boosts. Serological analysis revealed that both serum and mucus IgM levels of vaccinated fish were significantly higher $(p<0.05)$ after the $1^{\text {st }}$ week of post-vaccination and after each booster compared to control. The challenge trial against $S$. agalactiae at a $10^{9} \mathrm{CFU} / \mathrm{mL}$ concentration using both immersion and intraperitoneal (i.p) methods resulted in $80 \%$ and $70 \%$ survival rates, respectively. These findings indicated that spray administration effectively generated protective IgM antibodies providing moderate to high protection.

Another study by Kahieshesfandiari et al. [48] investigated the potential use of feed-based heat-inactivated biofilm vaccine of $S$. agalactiae. Chitin flakes were used to encapsulate the biofilm cells, and they compared the efficacy of the biofilm vaccine against the conventional heat-killed whole-cell vaccine in red hybrid tilapia. The vaccination regime was standardized between both types of vaccines. The vaccines were administered on week 0 and a booster on week two before the fish were subjected to the i.p challenge of a high concentration of $S$. agalactiae $\left(10^{9} \mathrm{CFU} / \mathrm{mL}\right)$. The results showed that tilapia vaccinated with biofilm vaccine exhibited significantly robust immune response $(\mathrm{p}<0.05)$ and high protection with the relative percent survival (RPS) of $87 \%$ as compared to fish vaccinated with the whole-cell vaccine $(57 \%)$. Besides that, they said that fish immunized with biofilm vaccine had significantly higher serum, mucus, and gut lavage antibody levels $(\mathrm{p}<0.05)$ than fish inoculated with the whole-cell vaccine or the control group. Furthermore, they discussed evidence for a high level of GALT activation in the form of lymphoid cell aggregations within the lamina propria.

Furthermore, continuous effort to develop an efficacious vaccine against streptococcosis has led the local researcher to investigate the potential application of a live-attenuated vaccine, another modern type of vaccine whereby the bacteria hold weakened or less virulent forms. Laith et al. [49] previously demonstrated that repeated 187 laboratory passage and chemical attenuation using acriflavine dye could weaken $S$. agalactiae. Primary oral administration of live-attenuated vaccine and booster at week 4 resulted 
in RPS of $82 \%$ after i.p challenge with a median lethal dose $\left(L D_{50}\right)$ of $S$. agalactiae. In addition, significant enhancements on the immune responses of tilapia were described, including elevated serum antibody (IgM) level and lysozyme activity.

\section{Development of a vaccine against $S$. iniae}

$\mathrm{R} \& \mathrm{D}$ of an oral vaccine against $S$. iniae was also undertaken by local researchers. Evidence of antigen localization in the gut of oral vaccinated and non-vaccinated red hybrid tilapia post-challenge with $S$. iniae was recently described by Hayat et al. [50]. A low number of antigens at $72 \mathrm{~h}$ post-challenge in the group receiving the routine oral vaccine (5 consecutive days and booster on days 14 and 21) displayed the simulation and irregular projection of M-cells with variable morphology and antigen distribution pattern. Further, they reported that fish immunized with biofilm vaccine had significantly higher antibody levels in their serum, mucus, and gut lavage $(p<0.05)$ than fish immunized with the whole-cell vaccine or the control group [51]. Moreover, they discussed evidence indicating a high level of GALT stimulation in the lamina propria in the form of lymphoid cell aggregations.

\section{Motile aeromonas septicemia (MAS) vaccine}

Infection with aeromonad bacteria causes MAS, which is most usually associated with $A$. hydrophila [71,72], but other species such as $A$. sobria $[71,73]$, $A$. veronii $[74,75]$, and $A$. caviae [76] have been documented to have a similar etiology in the past. The Aeromonas genus consists of many species. They are all motile, except for $A$. salmonicida, and most of them are ubiquitous inhabitants of different aquatic ecosystems [77]. The foremost, A. hydrophila, is predominantly responsible for most cases of MAS in freshwater fish worldwide. For example, in Malaysia, cases involving $A$. hydrophila have been reported in Clarias spp. [78], Pangasius spp. [79], and tilapia [80].

Perhaps this disease is sometimes overlooked since the infection's nature is typically associated with external stressors such as poor water quality or infection by another pathogen. Although the bacterial is often regarded as an opportunistic pathogen, it is easily transmitted from fish to fish, with hemorrhagic and ulcerated skin indicating the severity of infection. Depending on the strain of bacteria, the portal of entry, and mechanism of infection, fish infected with MAS can produce a diverse pattern of skin lesions [81], which indirectly affects the aesthetic quality of fish and market value, particularly in trading live fish. The previous research shows that the combination of various virulence factors might influence the pathogenicity of Aeromonas spp. in fish. Some of these virulence factors include exotoxins [82], exoenzymes [83], outer membrane protein (Omp) [84], and quorum sensing-controlled virulence factor [75].

The disease has resulted in severe economic losses to aquaculture. In 2009, an outbreak of A. hydrophila was reported in Brazil, affecting farmed hybrid surubim amounting to 20 tonnes in mortality and approximately USD 160,000 losses [85]. Peterman and Posadas [86] reported an estimated farm-gate loss of USD 2.6 million due to the disease within catfish aquaculture in east Mississippi during 2016. Another alarming concern on Aeromonas spp. is their increased resistance pattern against multiple antibiotics, especially those currently used in aquaculture $[87,88]$.

Several countries have actively worked to address this issue, and vaccination is viewed as a viable option for preventing the disease. India, for example, has conducted substantial research on different types of vaccines, including inactivated vaccines, live attenuated vaccines, and biofilm vaccines, all of which are based on various components of $A$. hydrophila. Previously, extracellular protein, S-layer protein, lipopolysaccharide, and Omp were identified as viable candidates [89]. Although local researchers in Malaysia are not interested in developing a vaccine against $A$. hydrophila, this is likely due to its complicated serotype and variable in virulence gene expression [70,90]; many efforts have been conducted in recent years and are summarized in Table- 4 .

\section{Development of a vaccine against A. hydrophila}

Matusin [52] reported her successful attempt in developing a recombinant vaccine expressing the immunogenic genes of Omp (OmpTs and OmpW) of $A$. hydrophila. The genes were positively cloned into the pET102/D-TOPO vector, and trials were conducted in African catfish (Clarias gariephinus). Two vaccines were administered by injection at week- 0 followed by a booster at week-2 before being challenged with live virulent $A$. hydrophila. The RPS of vaccinated groups was recorded at $100 \%$ compared to the placebo group $(29.42 \%)$.

In contrast, Monir et al. [53] previously reported the effectiveness of a newly developed feed-based bivalent vaccine against $S$. iniae and $A$. hydrophila in combating both pathogens in tilapia. They discovered that following double booster vaccination regime (given on 0,14 , and 42 days), the number of leucocytes, monocytes, granulocytes, lysozyme, and phagocytic activity, and serum antibody (IgM) levels were significantly higher $(\mathrm{p}<0.05)$ in the vaccinated group as early as 21 days post-vaccination. In addition, the challenge test against $S$. iniae, A. hydrophila, and co-infection of these bacteria showed the RPS of $80 \%, 76.67 \%$, and $76.67 \%$, respectively.

More recently, another study by Aslah et al. [54] reported the effectiveness of a newly developed feedbased polyvalent vaccine against Vibrio harveyi, S. agalactiae, and A. hydrophila in Asian seabass. This appealing feature effectively controls several fish diseases by a single vaccination. They found that oral vaccination at $5 \%$ body weight has successfully stimulated high serum antibody $(\operatorname{IgM})$ production $(\mathrm{p}<0.05)$ against $V$. harveyi, A. hydrophila, and $S$. agalactiae, 
and serum lysozyme level. Gene expression analysis from vaccinated fish gut samples revealed significantly higher expression $(\mathrm{p}<0.05)$ of dendritic cells, complement-3, chemokine ligand 4, and major histocompatibility complex class I (MHC I) compared to the unvaccinated group. The experimental challenge resulted in RPS of $75 \%, 80 \%$, and $80 \%$ after i.p injection with $10^{7} \mathrm{CFU} / \mathrm{mL}$ of $V$. harveyi, $A$. hydrophila, and $S$. agalactiae, respectively.

\section{Vibriosis vaccine}

Vibriosis has been an issue in Malaysian marine aquaculture since 1973 [17], when the culture of marine finfish was established. However, it was not until the 1990s that sea bass, grouper, and snapper were frequently reported to be infected with the disease. Throughout the hatchery and grow-out phases, the fish are susceptible. Several Vibrio spp. have been discriminated against as etiological agents of the disease, including $V$. alginolyticus, Vibrio vulnificus, and Vibrio harveyi. In 1979, See-Yong et al. [19] reported red boil disease affecting cultured estuary grouper (E. salmoides) in floating cages in the Straits of Penang, Malaysia. Based on colony morphology on selective media and pathogenicity, they concluded that $V$. parahaemolyticus is the causative agent. The diseased fish were found darker in color with hemorrhagic abscesses. In addition, they reported that most cases were asymptomatic due to an acute course of infection. Another case involving greasy grouper (Epinephelus malabaricus), silver seabass (L. calcarifer), and golden snapper (L. johni) were formerly reported by Wong and Leong [91] affecting floating cages area in Penang and Perak, the northern region of Peninsular Malaysia. They found that Group I (consist of $V$. parahaemolyticus, $V$. alginolyticus, $V$. harveyi, and $V$. vulnificus) with 3 fish species, greasy grouper, silver seabass, and golden snapper predominately with $42 \%, 56 \%$, and $62 \%$ prevalence, respectively.

Moreover, vibriosis outbreaks are not limited to Peninsular Malaysia but rather spread across Borneo, East Malaysia. For example, Ransangan and Mustafa [92] reported a vibriosis outbreak of Asian seabass cultured in net cages in Sabah, Malaysia, in February 2008. Their work revealed that $V$. harveyi is the causative pathogen. The fish were characterized by deep skin and fin ulceration, dark pigmentation, lack of appetite, ascites in the body cavity, and enlarged liver and spleen. Further analysis discovered that the isolated $V$. harveyi displayed high virulence with a median lethal dose $\left(\mathrm{LD}_{50}\right)$ of $1.4 \times 10^{4} \mathrm{CFU} \mathrm{g}^{-1}$ in Asian seabass and $8.33 \times 10^{3} \mathrm{CFU} \mathrm{g}^{-1}$ in humpback grouper [93].

Recently, in September 2016, a concurrent infection by $V$. harveyi and $V$. alginolyticus was reported affecting cultured hybrid groupers reared in marine floating cage-culture of Selangor, Malaysia [94]. Within 10 days, $29 \%$ of the farm's juvenile groupers died. Clinical symptoms and signs such as lethargy, increased mucus secretion, rotting fins, liver and kidney congestion, and spleen enlargement were all seen in the diseased groupers, whereas generalized congestion of the brains and internal organs was also reported. Interestingly, other cultured fish species produced in the exact location, such as Asian seabass, snapper, and golden pompano, were not harmed. More recently, according to Amalina et al. [95], the distribution of Vibrio spp. isolated from cultured groupers in Peninsular Malaysia was predominated by $V$. vulnificus, $V$. alginolyticus, and $V$. parahaemolyticus with $33 \%, 24 \%$, and $22 \%$, respectively. Thus, vibriosis has remained a severe problem in Malaysian cultured marine fish since the $90 \mathrm{~s}$, resulting in significant economic losses. Total losses among Malaysia's three main grouper, snapper, and seabass culture species were USD 7.4 million in 1990 [95].

According to a recent assessment on the management costs of Asian seabass cage culture in Malaysia, the average loss due to vibriosis was calculated to be USD0.24/tail, which can be broken down into mortality of $79.2 \%$, treatment of $20.8 \%$, and diagnosis of $1.25 \%$ [96]. As a result, the development of an effective vaccination approach to prevent disease epidemics is desirable.

\section{Development of a vaccine against Vibrio harveyi}

One of the earliest attempts by local researchers was reported byMohd-Aris et al. [97], who discovered virulence-associated genes, serine protease (VHS), and OMP from pathogenic $V$. harveyi. Using computational prediction, further characterization of these genes revealed that both VHS and OMP are composed of 62 and 36 antigenic sites, potentially developing an effective live-attenuated vaccine candidate. Following success in the characterization of $V$. harveyi vaccine candidates, a live-attenuated vaccine was developed by selective gene deletion of virulence-associated protease and subjected to vaccination trial in tiger grouper [55]. In week 4, a single dose vaccination regime was employed before the fish was challenged with $V$. harveyi. Their work achieved a moderate satisfactory RPS of $52 \%$. At the same time, transcriptomic profiling revealed the upregulation of the autophagosome pathway, coagulation, complement cascade pathways, and antigen processing and presentation pathways. Another trial of the same vaccine was reported by Chin et al. [56], embarking on different fish species of Asian seabass, different vaccine routes of bath immersion, and double dose regime, resulting in improved efficacy. The vaccine was administered on day 0 and 14 before the fish were challenged by immersion at $10^{7} \mathrm{CFU} / \mathrm{mL}$ of $V$. harveyi. RPS was recorded at $68 \%$, and higher expression $(\mathrm{p}<0.05)$ of the chemokine ligand-4 and MHC I genes in the skin and liver of vaccinated fish was noted.

Classical preparation of the killed vaccine has also proved effective in combating $V$. harveyi infection. Abu Nor et al. [98] recently reported that double 
dose injection of formalin-killed whole-cell vaccine of $V$. harveyi was successfully reduced mortality in marine red hybrid tilapia to $16 \%$ after the fish were intraperitoneally challenged with $10^{8} \mathrm{CFU} / \mathrm{mL}$ of $V$. harveyi at week 4. A significant increment $(\mathrm{p}<0.05)$ in IgM serum, mucus, and gut lavage antibody titer and lysozyme activities was achieved as early as 1-week post-vaccination.

\section{Development of a vaccine against $V$. alginolyticus}

Omp has long been recognized as a potential vaccine candidate in most Gram-negative bacteria, owning to its highly conserved region across serotypes and virulence attributes [99]. Besides, scholars reported the antigenic sites of $\mathrm{OmpK}$ and OmpW of $V$. alginolyticus consisting of 34 and 27 antigenic sites, respectively, and deemed suitable for vaccine candidates [57]. Interestingly, in an experimental trial, juvenile hybrid groupers were injected with inactivated Escherichia coli expressing the OmpK, and OmpW resulted in the RPS of $100 \%$ and $63 \%$, respectively, after i.p challenged with a high dose $\left(10^{9} \mathrm{CFU} / \mathrm{mL}\right)$ of a virulent strain of $V$. alginolyticus [58]. Besides, the IgM level against OmpK was significantly higher $(\mathrm{p}<0.05)$ than OmpW suggesting the superiority of the OmpK recombinant vaccine against $V$. alginolyticus infection.

More recently, recombinant OmpK vaccine versatility in providing cross-protection against different Vibrio species of $V$. harveyi, $V$. alginolyticus, and $V$. parahaemolyticus in Asian seabass has been reported [59]. Furthermore, in an experimental trial, a single i.p injection of recombinant OmpK vaccine resulted in 90-100\% survival after being challenged with a high concentration of $V$. harveyi, $V$. alginolyticus, and $V$. parahaemolyticus.

\section{Challenges and Future of Fish Vaccine in Malaysia}

\section{Commercialization of local vaccine}

Increase frequencies of emerging and re-emerging diseases among aquaculture fish species as witnessed in the past few years, resulting in considerable economic losses. This trend is expected to drive demand for commercial aquaculture vaccines locally and globally. Unfortunately, although local researchers have achieved a lot and massive investment in research grants, there is still no locally produced fish vaccine available in the country. In fact, other veterinary medical treatments for use in farmed aquatic animals are in severely short supply. This scenario is a severe impediment to disease prevention and response, resulting in welfare issues and stifling the growth of Malaysian aquaculture.

The commercialization of vaccines or any research product is a complex process, and there is no one-sizefits-all formula that will ensure its success [100]. It usually entails a lengthy process and requires a hefty investment; both are frequently a source of difficulty for researchers. Aside from these two crucial factors, several scholars have identified several issues that local researchers may confront when commercializing their research output. Lack of entrepreneurial knowledge and skill, the inefficiency of the Technology Transfer Center, the availability of potential licensee, linkage gaps between industry and researchers, limited workforce, and poor marketing strategies are additional challenges in bringing research outputs into the viable market [101-104]. A dynamic framework for effective commercialization of research products was proposed by Ismail et al. [100], consisting of eight elements: The researchers' knowledge, skills, and personal traits, product idea creation, development, packaging, and promotion, commercialization paths, gaining a competitive advantage in the market, selecting business partners, fostering a positive working relationship with business partners, and providing facilities and support.

Another hurdle in commercializing aquaculture vaccines in Malaysia is the limited availability of animal vaccine manufacturing plants. Like any other biological product, vaccines for commercial use should comply with good manufacturing guidelines. However, unlike conventional pharmaceutical goods, vaccine production involves biological processes such as microbe cultivation and extraction from living cells, which sometimes display intrinsic variability [105]. Therefore, stringent protocol at all production stages is applied, which can only be accomplished in a hightech manufacturing facility. Because of the cost and complexity of the operation, the vast majority of aquaculture vaccine supply currently comes from a handful of developed countries. Despite the fact that Southeast Asian countries produce some of the world's best fish and fisheries goods [106], Southeast Asian countries venturing into fish vaccine manufacturing is unheard of. Although the alliance is mostly composed of developing nations, establishing a regional aquaculture vaccine supply chain makes sense in terms of collective food security and supply, socioeconomic growth, and the sector's sustainability. A medium-sized central manufacturing facility and open-system bioreactors will ensure a low-resource environment and simplify the production of aquaculture vaccines against regionally significant fish diseases. Several factors, however, should be considered before committing to this capacity.

\section{Limited studies on vaccination field trial}

Field trials are required to accurately assess a vaccine's efficacy, safety, and overall performance in real-world settings. In contrast to controlled laboratory circumstances, the dynamic interaction between host, pathogen, and environment in a production setting can result in variances in immune response and vaccine effectiveness [107]. This event is significant for a fish vaccine for at least two reasons: First, site-specific water physiochemical profiles can affect fish immunity and disease occurrence, and second, physical rearing conditions can vary greatly depending on the 
rearing technology used [108]. As a result, field testing is a mandatory requirement for innovative vaccines intended for commercial use, and regulatory agencies require it prior to granting full authorization. To achieve successful testing, meticulous planning, full cooperation from farm operators, and massive investment are frequently required. Unfortunately, vaccine field trials in Malaysia are insufficient and should be expanded to expedite commercialization. The following sections describe some critical aspects of the fish vaccinology field trial.

\section{Establishing the vaccination protocol}

Researchers, farm managers, and operators should collaboratively develop a suitable field vaccination protocol. This step is crucial to ensure all parties involved in the study are aware of their roles and responsibilities and the importance of adhering to the protocol. This is because any deviation that occurs throughout the implementation might affect the trial's outcome. Therefore, investigators should carefully justify any unforeseen scenarios and provide immediate responses to minimize the study outcome's impact. Besides, the vaccination regime adopted in the field study must be supported by laboratory trial findings, and other practices should be resembling regular activities on the farm. A set of guidelines from the EU commission (EMA/CVMP/IWP/314550/2010) entitled "Guideline on the design of studies to evaluate the safety and efficacy of fish vaccines" is an excellent reference for this purpose.

\section{Site selection, epidemiology, and immune response monitoring}

The fish will be subjected to the disease's natural challenge in the field trial. Therefore, when selecting a trial site, researchers should examine the scale of the disease's spread and the number of new cases. There is a considerable probability of failure in the field vaccination trial due to the absence of the pathogen. The lack of disease outbreaks in the vaccinated fish population will result in insufficient evidence of vaccine efficacy because the challenge pressure remains unknown. Therefore, investigators should conduct important on-farm epidemiological surveillance to ascertain the critical period of infection and disease prevalence before conducting the vaccine trial.

Furthermore, the quality of the raw data collected during the trial is critical. Farm operators should be educated on the value of accurate record-keeping, which reflects the quality of the final product following the trial period. In addition, the use of mortality records between the vaccinated and control groups is frequently insufficient. It should be complemented by routine response monitoring, such as antibody titer, pathogen isolation, side effect score, and assessment of water quality. These parameters must be explicitly established in the study protocol and justified considering the vaccine's indications. If no outbreak occurs during the trial, this data can be used to provide evidence of the vaccine's immunological response. This correlate of protection can be used as an alternative outcome for vaccine evaluation [109].

\section{Control groups}

In most vaccination studies, a group of vaccinated fish is compared to an equivalent group of unvaccinated or placebo fish. The investigator should choose the controls to provide evidence of infection and represent a group of fish to which the vaccinated group can be compared legitimately. Two approaches are most commonly chosen in comparing these groups: (1) Comparison of vaccinated and control groups in the same captivity and (2) comparison between vaccinated and control groups kept in different but identical captivity within a similar farm. The first approach is customarily preferred since both fish groups will be subjected to equivalent conditions and challenges. Individual identification, such as pit tagging or specialized dye, can be used to accomplish this. This approach, however, is only possible for a vaccine that can be administered on an individual fish basis and is unsuitable for oral and immersion treatment. Besides, researchers should also consider the likelihood of the herd immunity effect, which occurs when a population of vaccinated fish becomes immune, making disease transmission to an unvaccinated group improbable.

\section{Lack of studies on viral vaccine}

For decades, R\&D on fish vaccines in Malaysia has been concentrated based on bacterial etiology. Although virus disease has been implicated in the local aquaculture industry since the 1990s, it is not the subject of interest by local researchers. This is most likely owing to the country's inadequate capacity and capability in this subject. Nowadays, only a few laboratories are prepared to maintain fish cell cultures and virus purification. In addition, producing a fish virus vaccine is indeed a very challenging and time-consuming process. The fish virus has many subtypes or serotypes, and vaccines derived from one subtype are typically less effective against other subtypes [110]. In addition, changes or mutations can occur when the virus reproduces rapidly in the infected fish [111], especially with the RNA virus. The mutation process is often disadvantageous for the viruses, but not always since certain viruses become stronger due to the mutation. Thus, in some cases, the previously developed vaccines are less effective or not effective at all against the newly mutated virus [112]. This phenomenon has caused vaccine development to be a never-ending story that consumes a great deal of expense.

\section{Future of fish vaccines in Malaysia}

Malaysia's aquaculture industry will continue to proliferate while preserving a competitive edge as market demand for fish increases. This tendency is highly correlated with population growth, rapid 
urbanization, increase in household income, and international trade expansion, all of which contributed to increased fish consumption per capita [113]. Besides, the industry has generated numerous employment and income generation to the locals and ensures national food security and advancing the sustainable fisheries agenda. Continuous industrial growth will reduce dependence on imported fisheries products while easing pressure on wild fish stocks. Regrettably, the aquaculture industry's rapid rise has been stymied by recurrent infectious disease outbreaks. Vaccination is considered a viable solution and might offer a brighter future to the industry. At present, fish vaccinations in Malaysia are still limited to a few farms and hatcheries. These operators engage in large-scale farming, hence have the financial means to invest in vaccinations.

The active role played by various organizations, including the Department of Fisheries, local fisheries associations, and universities in fish vaccines gaining wider local attention. Other than that, an increment in the public call for healthy (antibiotics-free) food is probably molding Malaysia's future of fish vaccinations. The use of vaccinations in aquaculture is being considered as a substitute for antimicrobial medications and chemotherapy. In response, the MyAP-AMR for 2017-2021opposed the irresponsible and uncontrol use of antibiotics in the food production industry. Indiscriminate use of antibiotics in aquaculture would greatly influence the environment due to drug residues, affecting water's natural microbiota and accelerating the development of antibiotic-resistant bacteria.

Furthermore, water contaminated by these untreated aquaculture effluents is recycled into agricultural land, resulting in elevated antibiotic residue levels in groundwater, hence further increasing the risk of antibiotic-resistant microbes. Alarmingly, evidence of multiple resistant bacteria and resistance genes has been previously reported in Malaysian aquaculture and its environs [114-116]. Vaccines, unlike antibiotics, are widely accepted as the safest, practical, and cost-effective way of preventing aquatic animal diseases. Vaccination has been shown to be critical to the success of Norwegian Atlantic salmon farming [117]. To summarize, salmon farming in Norway suffered significant losses in the 1980s because of salmonid Vibrio infections and furunculosis, and farmers relied heavily on antibiotics to battle the diseases. In response, a salmonid vibriosis immersion vaccine and an injectable Aeromonas salmonicida vaccine were developed and applied in the farms [118-120]. The vaccines' high effectiveness has successfully controlled the disease and immediately resulted in a decline of antibiotic dependence [121]. Therefore, we believe that the mass application of vaccines in the local aquaculture industry is beneficial by increasing the industry's resilience. On the other hand, a thorough analysis of the prospective market and sales of local fish vaccines is highly recommended and should be pursued. Then, with a better grasp of the industry's needs, competent authorities and local experts can continue their R\&D of fish vaccines.

\section{Conclusion}

The Malaysian government has licensed three aquatic vaccination products thus far, all of which are imported. Despite the encouraging milestones achieved by scholars, there are currently no locally produced fish vaccines accessible to protect against various economically relevant diseases. Currently, no local company manufactures aquaculture vaccines due to the complexity and high cost of development and manufacturing, the lengthy registration process, and inadequate scientific and technical competence. Therefore, the Malaysian government's continued support for businesses venturing into the aquatic vaccine manufacturing industry is crucial. For instance, the Malaysian government has launched the Malaysia Grand Challenge to promote research, development, commercialization, and innovation. These incentives are accessible to start-ups, small-and medium-enterprises, multinational corporations, and individuals moving into new areas. Besides, the development and commercialization of fish vaccines should be collaborative between researchers and private companies from the beginning of the process. We believed that successfully commercializing a local vaccine would spur the development of additional innovative fish vaccines against economically significant diseases such as vibriosis, streptococcosis, viral nervous necrosis, iridovirus disease, and TiLV would eventually benefit the aquaculture industry in the long run.

\section{Authors' Contributions}

MSMR and MF: Conceived and framed the main idea of this manuscript. MSMR: Prepared the first draft. The first draft was read, criticized, and corrected by AA, RR, NNM, NR and MF. MSMR and MF proofread the second draft and finalized the manuscript. All authors read and approved the final manuscript.

\section{Acknowledgments}

This work was supported by the Department of Fisheries Malaysia Development Fund (P21225010390001: Research on aquaculture fish disease and vaccine development/diagnosis kit).

\section{Competing Interests}

The authors declare that they have no competing interests.

\section{Publisher's Note}

Veterinary World remains neutral with regard to jurisdictional claims in published institutional affiliation.

\section{References}

1. Department of Fisheries Malaysia. (2020) Annual Fisheries Statistic 2020. Aquaculture Table. Vol. 1. Malaysia: Department of Fisheries Malaysia. Available from: 
https://www.dof.gov.my/sumber/perangkaan-perikanan-i Retrieved on 12-09-2021.

2. Wan Norhana, M.N., Gerald, M.J. and Rozana, J. (2020) Aquaculture component of a national action plan on antimicrobial resistance in Malaysia. Asian Fish. Sci., 33S(S1): 90-96.

3. Department of Fisheries Malaysia. (2019) Annual Fisheries Statistic 2019. Vol. 1. Department of Fisheries Malaysia, Malaysia. Available from: https://www.dof.gov.my/ sumber/i-extension/perangkaan-tahunan Retrieved on 12-09-2021.

4. Department of Fisheries Malaysia. (2016-2018) Annual Fisheries Statistic 2016-2019. Vol. 1. Department of Fisheries Malaysia, Malaysia. Available from: https:// www.dof.gov.my/sumber/i-extension/perangkaan-tahunan Retrieved on 12-09-2021.

5. FAO (Food and Agriculture Organization of the United Nations). (2020) The State of World Fisheries and Aquaculture 2020. Sustainability in Action. Food and Agriculture Organization of the United Nations, Rome, Italy.

6. Tacon, A.G.J. (2020) Trends in global aquaculture and aquafeed production: 2000-2017. Rev. Fish. Sci. Aquat., 28(1): 43-56.

7. Sayuthi, S. (1993) Fish diseases in Malaysia: Status and problems. In: Proceedings of the Aquaculture Workshop for SEAFDEC/AQD Training Alumni, 8-11 Sept. 1992, Iloilo, Philippines. SEAFDEC Aquaculture Department, Iloilo, Philippines, p173.

8. Siti Hawa, A., Mohd Syafiq, M.R., Siti-Zahrah, A., NurNazifah, M., Firdaus-Nawi, M., Zamri-Saad, M. and Amal, M.N.A. (2020) Retrospective identification of bacterial depository revealed that Streptococcus iniae was responsible for some of the streptococcosis cases in cultured red tilapia in Malaysia since 2006. Pertanika J. Trop. Agric. Sci., 43(2): 231-238.

9. Aisyhah, M.A.S., Amal, M.N.A., Zamri-Saad, M., Siti-Zahrah, A. and Shaqinah, N.N. (2015) Streptococcus agalactiae isolates from cultured fishes in Malaysia manifesting low resistance pattern towards selected antibiotics. J. Fish Dis., 38(12): 1093-1098.

10. Siti-Zahrah, A. (1992) Common bacterial diseases of catfish, Clarias macrocephelus, cultured in Malacca. In: Proceedings of the National Intensification of Research in Priority Areas (IRPA) Seminar. Vol. II. Ministry of Science, Technology, and Environment, Kuala Lumpur, Malaysia.

11. Abdullah, A., Ramly, R., Ridzwan, M.S.M., Sudirwan, F., Abas, A., Ahmad, K., Murni, M. and Kua, B.C. (2018) First detection of tilapia lake virus (TiLV) in wild river carp (Barbonymus schwanenfeldii) at Timah Tasoh Lake, Malaysia. J. Fish Dis., 41(9): 1459-1462.

12. Amal, M.N.A., Koh, C.B., Nurliyana, M., Suhaiba, M., Nor-Amalina, Z., Santha, S., Diyana-Nadhirah, K.P., Yusof, M.T., Ina-Salwany, M.Y. and Zamri-Saad, M. (2018) A case of natural co-infection of tilapia lake virus and Aeromonas veronii in a Malaysian red hybrid tilapia (Oreochromis niloticus $\times$ O. mossambicus) farm experiencing high mortality. Aquaculture, 485: 12-16.

13. Miccoli, A., Manni, M., Picchietti, S. and Scapigliati, G. (2021) State-of-the-art vaccine research for aquaculture use: The case of three economically relevant fish species. Vaccines, 9(2): 140.

14. Standish, I.F., Brenden, T.O. and Faisal, M. (2016) Does herd immunity exist in aquatic animals? Int. J. Mol. Sci., 17(11): 1898.

15. Department of Veterinary Services Malaysia. (2019) Flow Chart of Veterinary Vaccine Registration. Department of Veterinary Services Malaysia, Malaysia. Available from: http://www.dvs.gov.my/index.php/pages/view/380 Retrieved on 12-09-2021.

16. Department of Veterinary Services Malaysia. (2020) List of Approved Veterinary Vaccines. Department of Veterinary
Services Malaysia, Malaysia. Available from: http:// www.dvs.gov.my/index.php/pages/view/380 Retrieved on 12-09-2021.

17. Leong, T.S. (1997) Control of parasites in cultured marine finfishes in Southeast Asia-an overview. Int. J. Parasitol., 27(10): 1177-1184.

18. Chuah, T.T. (2001) Survey of grouper diseases in Malaysia. In: Report and proceeding of APEC FWG Project 02/2000 "Development of a Regional Research Programme on Grouper Virus Transmission and Vaccine Development". Asia Pacific Economic Cooperation (APEC), Aquatic Animal Health Research Institute (AAHRI), Fish Health Section of the Asian Fisheries Society (FHS/AFS), and the Network of Aquaculture Centres in Asia-Pacific (NACA), Bangkok, Thailand. p38-40.

19. See-Yong, W., Ong, B. and Thia-Eng, C. (1979) Isolation, identification of causative agent of 'Red Boil Disease' in Grouper (Epinephilus salmoides) and its possible control by vaccination. In: Proceeding of the International Workshop on Pen Cage Culture of Fish, 11-12 Feb. 1979, Tigbauan, Iloilo, Philippines. Aquaculture Department, Southeast Asian Fisheries Development Center, Tigbauan, Iloilo, Philippines, p81-87.

20. Siti-Zahrah, A., Palanisamy, V., Chuah, T.T., Kua, B.C., Azila, A. and Vijayenthy, N. (2003) Experimental vaccine trials using Alpharma vaccine against vibriosis on Lutjanus argentimaculatus in laboratory condition. FRI Newslett., 8(1-2): 14-15.

21. Siti-Zahrah, A., Misri, S., Padilah, B., Zulkafli, R., Kua, B.C., Azila, A. and Rimatulhana, R. (2004) Predisposing factors associated with the outbreak of streptococcal infection in floating cage-cultured tilapia in reservoirs. In: $7^{\text {th }}$ Asian Fisheries Forum 04 Abstracts. Triennial Meeting of the Asian Fisheries Society, Penang, Malaysia. p420.

22. Siti-Zahrah, A., Padilah, B., Azila, A., Rimatulhana, R. and Shahidan, H. (2008) Multiple streptococcal species infection in cage-cultured red tilapia but showing similar clinical signs. In: Bondad-Reantaso, M.G., Mohan, C.V., Crumlish, M. and Subasinghe, R.P., editors. Diseases in Asian Aquaculture VI. Proceedings of the Sixth Symposium on Asian Aquaculture. Fish Health Section of the Asian Fisheries Society, Colombo, Sri Lanka. p313-320.

23. Pei-Chih, L., Yi-Lun, T., Yao-Chung, C., Pei-Chi, W., ShuChu, L. and Shih-Chu, C. (2020) Analysis of streptococcal infection and correlation with climatic factors in cultured tilapia Oreochromis spp. in Taiwan. Appl. Sci., 10(11): 4018.

24. Mishra, A., Gyu-Hwi, N., Jeong-An, G., Hee-Eun, L., Jo, A. and Heui-Soo, K. (2018) Current challenges of Streptococcus infection and effective molecular, cellular, and environmental control methods in aquaculture. Mol. Cell., 41(6): 495-505.

25. Zamri-Saad, M., Amal, M.N.A. and Siti-Zahrah, A. (2010) Pathological changes in red tilapias (Oreochromis spp.) naturally infected by Streptococcus agalactiae. J. Comp. Pathol., 143(2-3): 227-229.

26. Laith, A.A., Ambak, M.A., Hassan, M., Sheriff, S.M., Nadirah, M., Draman, A.S., Wahab, W., Ibrahim, W.N.W., Aznan, A.S., Jabar, A. and Najiah, M. (2017) Molecular identification and histopathological study of natural Streptococcus agalactiae infection in hybrid tilapia (Oreochromis niloticus). Vet. World, 10(1): 101-111.

27. Amal, M.N.A., Siti-Zahrah, A., Zulkafli, R., Misri, S., Ramley, A. and Zamri-Saad, M. (2008) The effect of water temperature on the incidence of Streptococcus agalactiae infection in cage-cultured tilapia. In: Proceedings of the International Seminar on Management Strategies on Animal Health and Production Control in Anticipation of Global Warming, Surabaya, Indonesia. p48-51.

28. Najiah, M., Aqilah, N.I., Lee, K.L., Khairulbariyyah, Z., Mithun, S., Jalal, K.C.A., Shaharom-Harrison, F. and 
Nadirah, M. (2012) Massive mortality associated with Streptococcus agalactiae infection in cage-cultured red hybrid tilapia Oreochromis niloticus in Como River, Kenyir Lake, Malaysia. J. Biol. Sci., 12(8): 438-442.

29. Amal, M.N.A., Zamri-Saad, M., Zulkafli, A.R., SitiZahrah, A., Misri, S., Ramley, B., Shahidan, H. and Sabri, M.Y. (2010) Water thermocline confirms susceptibility of tilapia cultured in lakes to Streptococcus agalactiae. J. Anim. Vet. Adv., 9(22): 2811-2817.

30. Rodkhum, C., Kayansamruaj, P. and Pirarat, N. (2011) Effect of water temperature on susceptibility to Streptococcus agalactiae serotype Ia infection in Nile tilapia (Oreochromis niloticus). Thai J. Vet. Med., 41(3): 309-314.

31. Zamri-Saad, M., Amal, M.N.A., Siti-Zahrah, A. and Zulkafli, A.R. (2014) Control and prevention of streptococcosis in cultured tilapia in Malaysia: A review. Pertanika J. Trop. Agric. Sci., 37(4): 389-410.

32. Syuhada, R., Zamri-Saad, M., Ina-Salwany, M.Y., Mustafa, M., Nasruddin, N.N., Desa, M.N.M., Nordin, S.A., Barkham, T. and Amal, M.N.A. (2020) Molecular characterisation and pathogenicity of Streptococcus agalactiae serotypes Ia ST7 and III ST283 isolated from cultured red hybrid tilapia in Malaysia. Aquaculture, 515: 734543.

33. Suphia-Amiera, S. (2019) Molecular Characterisation of Streptoccocus agalactiae Virulence Gene Isolated from Malaysian Hybrid Tilapia (Oreochromis spp.) (Master's Thesis, International Islamic University Malaysia, Kuantan, Malaysia). Available from: http://www.studentrepo.iium. edu.my/handle/123456789/9406. Retrieved on 27-09-2021.

34. Amal, M.N.A., Zamri-Saad, M., Siti-Zahrah, A., Zulkafli, A.R. and Nur-Nazifah, M. (2013) Molecular characterisation of Streptococcus agalactiae strains isolated from fishes in Malaysia. J. Appl. Microbiol., 115(1): 20-29.

35. Sun, J., Fang, W., Ke, B., He, D., Liang, Y., Ning, D., Tan, H., Peng, H., Wang, Y., Ma, Y. and Ke, C. and Deng, X. (2016) Inapparent Streptococcus agalactiae infection in adult/commercial tilapia. Sci. Rep., 6: 26319.

36. Leal, C.A.G., Queiroz, G.A., Pereira, F.L., Tavares, G.C. and Figueiredo, H.C.P. (2019) Streptococcus agalactiae sequence type 283 in farmed fish, Brazil. Emerg. Infect. Dis., 25(4): 776-779.

37. Piamsomboon, P., Thanasaksiri, K., Murakami, A., Fukuda, K., Takano, R., Jantrakajorn, S. and Wongtavatchai, J. (2020) Streptococcosis in freshwater farmed seabass Lates calcarifer and its virulence in Nile tilapia Oreochromis niloticus. Aquaculture, 523: 735189.

38. Al-Harbi, A.H. (2016) Phenotypic and genotypic characterisation of Streptococcus agalactiae isolated from hybrid tilapia (Oreochromis niloticus $\times O$. aureus). Aquaculture, 464: 515-520.

39. Klesius, P., Shoemaker, C.A. and Evans, J. (2008) Streptococcus: A worldwide fish health problem. In: Proceedings of the Eight International Symposium on Tilapia in Aquaculture, 12-14 Oct. 2008, Cairo, Eygpt. p7.

40. Amal, M.N.A. and Zamri-Saad, M. (2011) Streptococcosis in tilapia (Oreochromis niloticus): A review. Pertanika J. Trop. Agric. Sci., 34(2): 195-206.

41. Firdaus-Nawi, M., Yusoff, S.M., Hanan, Y., Siti-Zahrah, A. and Zamri-Saad, M. (2013) Efficacy of feed-based adjuvant vaccine against Streptococcus agalactiae in Oreochromis spp. in Malaysia. Aquac. Res., 45(1): 87-96.

42. Ismail, M.S., Siti-Zahrah, A., Syafiq, M.R.M., Amal, M.N.A., Firdaus-Nawi, M. and Zamri-Saad, M. (2016) Feed-based vaccination regime against streptococcosis in red tilapia, Oreochromis niloticus $\times$ Oreochromis mossambicus. BMC Vet. Res., 12(1): 194.

43. Ismail, M.S., Syafiq, M.R., Siti-Zahrah, A., Fahmi, S., Shahidan, H., Hanan, Y., Amal, M.N.A. and ZamriSaad, M. (2016) The effect of feed-based vaccination on tilapia farm endemic for streptococcosis. Fish Shellfish Immunol., 60: 21-24.

44. Nur-Nazifah, M., Sabri, M.Y. and Siti-Zahrah, A. (2014)
Development and efficacy of feed-based recombinant vaccine encoding the cell wall surface anchor family protein of Streptococcus agalactiae against streptococcosis in Oreochromis sp. Fish Shellfish Immunol., 37(1): 193-200.

45. Nadirah, A.N. (2015) Field Evaluation of Feed-Based Recombinant Protein Adjuvanted Vaccine Against Streptococcosis in Red Hybrid Tilapia (Oreochromis sp.) (Master's Thesis, Universiti Putra Malaysia, Serdang, Malaysia). Available from: http://www.psasir.upm.edu.my/ id/eprint/65741. Retrieved on 27-09-2021.

46. Sa'aidatun Asyikin, A., Farina, M.K., Zamri-Saad, M., Siti-Zahrah, A., Mohd Syafiq, M.R., Hanan, M.Y., Shahidan, H., Fahmi, S., Ismail, M.S. and Suphia-Amiera, S. (2018) Effect of incorporating different concentrations of palm oil as an adjuvant in the fish vaccine. Int. J. Biosci., 12(1): $35-41$.

47. Noraini, O., Sabri, M.Y. and Siti-Zahrah, A. (2013) Efficacy of spray administration of formalin-killed Streptococcus agalactiae in hybrid red tilapia. J. Aquat. Anim. Health., 25(2): 142-148.

48. Kahieshesfandiari, M., Sabri, M.Y., Ina-salwany, M.Y., Hassan, M.D., Noraini, O., Ajadi, A.A. and Isiaku, A.I. (2019) Streptococcosis in Oreochromis sp.: Is feed-based biofilm vaccine of Streptococcus agalactiae effective? Aquac. Int., 27(3): 817-832.

49. Laith, A.A., Abdullah, M.A., Nurhafizah, W.W.I., Hussein, H.A., Aya, J., Effendy, A.W.M. and Najiah, M. (2019) Efficacy of live attenuated vaccine derived from the Streptococcus agalactiae on the immune responses of Oreochromis niloticus. Fish Shellfish Immunol., 90: 235-243.

50. Hayat, M., Sabri, M.Y., Intan-Shameha, A.R., InaSalwany, M.Y. and Thompson, K.D. (2020) Localisation of antigens in the gut post-challenge with Streptococcus iniae in vaccinated and non-vaccinated red hybrid tilapia (Oreochromis sp.). Aquac. Int., 28(4): 1739-1752.

51. Hayat, M., Sabri, M., Yusoff, M., Samad, M.J., Shameha, I., Razak, A., Ina Salwany, M.Y., Thompson, K.D. and Hasni, K. (2021) Efficacy of feed-based formalin-killed vaccine of Streptococcus iniae stimulates the gut-associated lymphoid tissues and immune response of red hybrid tilapia. Vaccines, 9(1): 51 .

52. Matusin, S. (2015) Molecular Characterisation of Aeromonas hydrophila and Development of Recombinant cells vaccine expressing outer membrane proteins Against its in African Catfish (Clarias gariepinus Burchell) (Master's Thesis, Universiti Putra Malaysia, Serdang, Malaysia). Available from: http://www.psasir.upm.edu.my/ $\mathrm{id} /$ eprint/59059. Retrieved on 27-09-2021.

53. Monir, M.S., Yusoff, S.M., Zulperi, Z.M., Hassim, H.A., Mohamad, A., Hafiz Ngoo, M.S.M. and Ina-Salwany, M.Y. (2020) Haemato-immunological responses and effectiveness of the feed-based bivalent vaccine against Streptococcus iniae and Aeromonas hydrophila infections in hybrid red tilapia (Oreochromis mossambicus $\times$ O. niloticus). BMC Vet. Res., 16: 226.

54. Aslah, M., Zamri-Saad, M., Amal, M.N.A., Al-saari, N., Monir, M.S., Chin, Y.K. and Ina-Salwany, M.Y. (2021) Vaccine efficacy of a newly developed feed-based wholecell polyvalent vaccine against vibriosis, streptococcosis and motile aeromonad septicemia in Asian seabass, Lates calcarifer. Vaccines, 9(4): 368.

55. Mohd-Aris, A., Zamri-Saad, M., Hassan, M.D., Yusof, M.T. and Ina-Salwany, M.Y. (2019) Vibrio harveyi protease deletion mutant as a live attenuated vaccine candidate against vibriosis and transcriptome profiling following vaccination for Epinephelus fuscoguttatus. Aquac. Int., 27(1): 125-140.

56. Chin, Y.K., Al-saari, N., Zulperi, Z., Mohd-Aris, A., Salleh, A., Silvaraj, S., Aslah, M., JingYie, L., ZamriSaad, M. and Ina-Salwany, M.Y. (2020) Efficacy of bath vaccination with a live attenuated Vibrio harveyi against vibriosis in Asian seabass fingerling, Lates calcarifer. 
Aquac. Res., 51(1): 389-399.

57. Nehlah, R., Ina-Salwany, M.Y. and Zulperi, Z. (2016) Antigenicity analysis and molecular characterisation of two outer membrane proteins of Vibrio alginolyticus strain VA2 as vaccine candidates in tiger grouper culture. J. Biol. Sci., 16(1-2): 1-11.

58. Nehlah, R., Firdaus-Nawi, M., Nik-Haiha, N.Y., Karim, M., Zamri-Saad, M. and Ina-Salwany, M.Y. (2017) Recombinant vaccine protects juvenile hybrid grouper, Epinephelus fuscoguttatus $\times$ Epinephelus lanceolatus, against infection by Vibrio alginolyticus. Aquac. Int., 25(6): 2047-2059.

59. Silvaraj, S., Md Yasin, I.S., A. Karim, M.M. and Saad, M.Z. (2020) Elucidating the efficacy of vaccination against vibriosis in Lates calcarifer using two recombinant protein vaccines containing the outer membrane protein $\mathrm{K}(\mathrm{r}-\mathrm{OmpK})$ of Vibrio alginolyticus and the DNA Chaperone J (r-DnaJ) of Vibrio harveyi. Vaccines, 8(4): 660.

60. Galindo-Villegas, J., Tobar, J.A., Mutoloki, S., Mweemba Munang'andu, H. and Evensen, Ø. (2015) Oral vaccination of fish-antigen preparations, uptake, and immune induction. Front. Immunol., 6: 519.

61. Somamoto, T. and Nakanishi, T. (2020) Mucosal delivery of fish vaccines: Local and systemic immunity following mucosal immunizations. Fish Shellfish Immunol., 99: 199-207.

62. Sharma, A., Gautam, S. and Bandyopadhyay, N. (1999) Enzyme immunoassays: Overview. In: Batt, C.A. and Tortorello, M.L., editor. Encyclopedia of Food Microbiology. $2^{\text {nd }}$ ed. Academic Press, Massachusetts. p625-633.

63. de las Heras, A.I., Rodríguez Saint-Jean, S. and PérezPrieto, S.I. (2010) Immunogenic and protective effects of an oral DNA vaccine against infectious pancreatic necrosis virus in fish. Fish Shellfish Immunol., 28(4): 562-570.

64. Zhang, W., Zhu, C., Chi, H., Liu, X., Gong, H., Xie, A., Zheng, W., Chen, J., Zhang, N. and Wu, Y. (2021) Early immune response in large yellow croaker (Larimichthys crocea) after immunization with the oral vaccine. Mol. Cell. Probes, 56: 101708.

65. Ramos-Espinoza, F.C., Cueva-Quiroz, V.A., YunisAguinaga, J., Alvarez-Rubio, N.C., Paganoti de Mello, N. and Engrácia de Moraes, J.R. (2020) Efficacy of two adjuvants administrated with a novel hydrogen peroxide-inactivated vaccine against Streptococcus agalactiae in Nile tilapia fingerlings. Fish Shellfish Immunol., 105(4): 350-358.

66. Sun, B., Yu, S., Zhao, D., Guo, S., Wang, X. and Zhao, K. (2018) Polysaccharides as vaccine adjuvants. Vaccine, 36(35): 5226-5234.

67. Firdaus-Nawi, M., Noraini, O., Sabri, M.Y., Siti-Zahrah, A., Zamri-Saad, M. and Latifah, H. (2011) The effects of oral vaccination of Streptococcus agalactiae on stimulating gut-associated lymphoid tissues (GALTs) in tilapia (Oreochromis spp.). Pertanika J. Trop. Agric. Sci., 34(1): 137-143.

68. Aiyer Harini, P., Ashok Kumar, H., Gupta Praveen, K. and Shivakumar, N. (2013) An overview of immunologic adjuvants-a review. J. Vaccines Vaccin., 4(1): 1000167.

69. Mufti, A., Kumolosaso, E. and Shamsuddin, A.F. (2017) Physiochemical characterization and stability studies of duck pasteurellosis nanovaccine using palm oil (MCTLCT) lipid emulsion as an adjuvant. Acta Pol. Pharm., 74(4): 1167-1175.

70. Wang, Q., Ji, W. and Xu, Z. (2020) Current use and development of fish vaccines in China. Fish Shellfish Immunol., 96: 223-234.

71. Yardimci, R.E. and Turgay, E. (2021) Diagnosis of Aeromonas sobria and Saprolegnia sp. co-infection in rainbow trout fry (Oncorhynchus mykiss). Aquat. Res., 4(1): 65-72.

72. Fowoyo, P.T. and Achimugu, F. (2019) Virulence of Aeromonas hydrophila isolated from freshwater catfish. J. Biosci. Med., 7(1): 1-12.

73. Majtán, J., Černy, J., Ofúkana, A., Takáč, P., and
Kozánek, M. (2012) Mortality of therapeutic fish garra rufa caused by Aeromonas sobria. Asian Pac. J. Trop. Biomed., 2(2): 85-87.

74. Shameena, S.S., Kumar, K., Kumar, S., Kumar, S., and Rathore, G. (2020) Virulence characteristics of Aeromonas veronii biovars isolated from infected freshwater goldfish (Carassius auratus). Aquaculture, 518: 734819.

75. Li, T., Raza, S.H.A., Yang, B., Sun, Y., Wang, G., Sun, W., Qian, A., Wang, C., Kang, Y. and Shan, X. (2020) Aeromonas veronii Infection in commercial freshwater fish: A potential threat to public health. Animals, 10(4): 608.

76. Roy, A., Singha, J. and Abraham, T.J. (2018) Histopathology of Aeromonas caviae infection in challenged Nile tilapia Oreochromis niloticus (Linnaeus, 1758). Int. J. Aquac., 8(20): 151-155.

77. Stratev, D. and Odeyemi, O.A. (2017) An overview of motile Aeromonas septicaemia management. Aquac. Int., 25(3): 1095-1105.

78. Laith, A.A. and Najiah, M. (2013) Aeromonas hydrophila: Antimicrobial susceptibility and histopathology of isolates from diseased catfish, Clarias gariepinus (Burchell). J. Aquac. Res. Dev., 5(2): 1000215.

79. Mahmood, S., Mansor, N.N., Abdullah, S., Chowdhury, A., Ramly, R. and Amal, M.N.A. (2019) Assessment of bacteria and water quality parameters in cage cultured Pangasius hypophthalmus in Temerloh, Pahang River, Malaysia. Nat. Environ. Pollut. Technol., 18(5): 1479-1486.

80. Pauzi, N.A., Mohamad, N., Azzam-Sayuti, M., InaSalwany, M.Y., Zamri-Saad, M., Nasruddin, N.S. and Amal, M.N.A. (2020) Antibiotic susceptibility and pathogenicity of Aeromonas hydrophila isolated from red hybrid tilapia (Oreochromis niloticus $\times$ Oreochromis mossambicus) in Malaysia. Vet. World, 13(10): 2166-2171.

81. Baumgartner, W.A., Lorelei, F. and Hanson, L. (2017) Lesions caused by virulent Aeromonas hydrophila in farmed catfish (Ictalurus punctatus and I. punctatus $\times I$. furcatus) in Mississippi. J. Vet. Diagn. Invest., 29(5): 747-751.

82. Roges, E.M., Gonçalves, V.D., Cardoso, M.D., Festivo, M.L., Siciliano, S., Berto, L.H., Pereira, V.L.A., Rodrigues, D.D.P. and de Aquino, M.H.C. (2020) Virulenceassociated genes and antimicrobial resistance of Aeromonas hydrophila isolates from animal, food, and human sources in Brazil. Biomed Res. Int., 2020: 1052607.

83. Ji, Y., Li, J., Qin, Z., Li, A., Gu, Z., Liu, X., Lin, L. and Zhou, Y. (2015) Contribution of nuclease to the pathogenesis of Aeromonas hydrophila. Virulence, 6(5): 515-522.

84. Yadav, S.K., Meena, J.K., Sharma, M. and Dixit, A. (2016) Recombinant outer membrane protein $\mathrm{C}$ of Aeromonas hydrophila elicits mixed immune response and generates agglutinating antibodies. Immunol. Res., 64(4): 1087-1099.

85. da Silva, B.C., Mouriño, J.L.P., Vieira, F.N., Jatobá, A., Seiffert, W.Q. and Martins, M.L. (2012) Haemorrhagic septicaemia in the hybrid surubim (Pseudoplatystoma corruscans $\times$ Pseudoplatystoma fasciatum) caused by Aeromonas hydrophila. Aquac. Res., 43(6): 908-916.

86. Peterman, M.A. and Posadas, B.C. (2019) Direct economic impact of fish diseases on the East Mississippi catfish industry. N. Am. J. Aquac., 81(3): 222-229.

87. Stratev, D. and Odeyemi, O.A. (2016) Antimicrobial resistance of Aeromonas hydrophila isolated from different food sources: A mini-review. J. Infect. Public Health, 9(5): 535-544.

88. Saengsitthisak, B., Chaisri, W., Punyapornwithaya, V., Mektrirat, R., Klayraung, S., Bernard, J.K. and Pikulkaew, S. (2020) Occurrence and antimicrobial susceptibility profiles of multidrug-resistant aeromonads isolated from freshwater ornamental fish in Chiang Mai province. Pathogens, 9(11): 973.

89. Nayak, S.K. (2020) Current prospects and challenges in fish vaccine development in India with special reference to Aeromonas hydrophila vaccine. Fish Shellfish Immunol., 100: 283-299. 
90. Mzula, A., Wambura, P.N., Mdegela, R.H. and Shirima, G.M. (2019) Current state of modern biotechnological-based Aeromonas hydrophila vaccines for aquaculture: A systematic review. Biomed Res. Int., 2019: 3768948.

91. Wong, S.Y. and Leong, T.S. (1990) A comparative study of Vibrio infections in healthy and diseased marine finfishes cultured in floating cages near Penang, Malaysia. Asian Fish. Sci., 3(3): 353-359.

92. Ransangan, J. and Mustafa, S. (2009) Identification of Vibrio harveyi isolated from diseased Asian seabass Lates calcarifer using 16S ribosomal DNA sequencing. J. Aquat. Anim. Health, 21(3): 150-155.

93. Ransangan, J., Lal, T.M. and Al-Harbi, A.H. (2012) Characterization and experimental infection of Vibrio harveyi isolated from diseased Asian seabass (Lates calcarifer). Malays. J. Microbiol., 8(2): 104-115.

94. Nurliyana, M., Aidil Roseli, M.F., Amal, M.N.A., Zamri-Saad, M., Ina-Salwany, M.Y., Zulkiply, N.A. and Nasruddin, N.S. (2019) Natural concurrent infection of Vibrio harveyi and V. alginolyticus in cultured hybrid groupers in Malaysia. J. Aquat. Anim. Health., 31(1): 88-96.

95. Amalina, N.Z., Dzarifah, Z., Amal, M.N.A., Yusof, M.T., Zamri-Saad, M., Al-saari, N., Tanaka, M., Mino, S., Sawabe, T. and Ina-Salwany, M.Y. (2019) Recent update on the prevalence of Vibrio species among cultured grouper in Peninsular Malaysia. Aquac. Res., 50(11): 3202-3210.

96. Norhariani, M.N., Siti Hajar, M.Y., Hassan, M.D., Amal, M.N.A. and Nurliyana, M. (2019) Costs of management practices of Asian seabass (Lates calcarifer Bloch, 1790) cage culture in Malaysia using a stochastic model that includes uncertainty in mortality. Aquaculture, 510: 347-352.

97. Mohd-Aris, A., Ina-Salwany, M.Y., Zamri-Saad, M., Hassan, M.D. and Norfarrah, M.A. (2016) Molecular characterization of Vibrio harveyi virulence-associated serine protease and outer membrane protein genes for vaccine development. Int. J. Biosci., 8(3): 10-28.

98. Abu Nor, N., Zamri-Saad, M., Ina-Salwany, M.Y., Salleh, A., Mustaffa-Kamal, F., Matori, M.F. and Amal, M.N.A. (2020) Efficacy of the whole cell inactivated Vibrio harveyi vaccine against vibriosis in a marine red hybrid tilapia (Oreochromis niloticus $\times$ O. mossambicus) model. Vaccines, 8(4): 734.

99. Maiti, B., Dubey, S., Munang'andu, H.M., Karunasagar, I., Karunasagar, I. and Evensen, Ø. (2020) Application of outer membrane protein-based vaccines against major bacterial fish pathogens in India. Front. Immunol., 11: 1362.

100. Ismail, N., Nor, M.J.M. and Sidek, S. (2015) A framework for a successful research products commercialization: A case of Malaysian academic researchers. Proc. Soc. Behav. Sci., 195: 283-292.

101. Khademi, T., Ismail, K., Tin Lee, C. and Shafaghat, A. (2015) Enhancing commercialisation level of academic research outputs in a research university. J. Teknol., 74(4): 141-151.

102. Ismail, N., Nor, M.J.M. and Sidek, S. (2017) Challenges for research product commercialisation: A case of Malaysian academic researchers. J. Eng. Appl. Sci., 12(6): 1543-1550.

103. Heng, L.H., Rasli, A.M. and Senin, A.A. (2012) Knowledge determinant in university commercialisation: A case study of Malaysia public university. Proc. Soc. Behav. Sci., 40: 251-257.

104. Latif, N.S.A., Abdullah, A. and Jan, N.M. (2016) A pilot study of entrepreneurial orientation towards commercialization of university research products. Proc. Econ. Finance, 37: 93-99.

105. WHO. (2016) Annex 3 WHO good manufacturing practices for biological products. In: WHO Technical Report Series
No. 999. World Health Organization, Geneva. Available from: https://www.who.int/publications/m/item/annex-2trs-no-999-who-gmp-for-biological-products. Retrieved on 12-09-2021.

106. SEAFDEC (Southeast Asian State of Fisheries and Aquaculture). (2017) Southeast Asian State of Fisheries and Aquaculture 2017. Southeast Asian Fisheries Development Center, Bangkok, Thailand. Available from: http://www. seafdec.org/download/southeast-asian-state-fisheries-aquaculture-2017. Retrieved on 12-09-2021.

107. Mitchell, H. (1997) The pitfalls of field trials in fish vaccinology. Dev. Biol. Stand., 90: 321-332.

108. Midtlyng, P.J. (2016) Methods for measuring efficacy, safety and potency of fish vaccines. In: Adams, A., editor. Fish Vaccines. $1^{\text {st }}$ ed. Springer, Basel. p119-141.

109. Knight-Jones, T.J.D., Edmond, K., Gubbins, S. and Paton, D.J. (2014) Veterinary and human vaccine evaluation methods. Proc. Biol. Sci., 281(1784): 20132839.

110. Crane, M. and Hyatt, A. (2011) Viruses of fish: An overview of significant pathogens. Viruses, 3(11): 2025-2046.

111. Stepien, C.A., Pierce, L.R., Leaman, D.W., Niner, M.D. and Shepherd, B.S. (2015) Gene diversification of an emerging pathogen: A decade of mutation in a novel fish Viral Hemorrhagic Septicemia (VHS) substrain since its first appearance in the Laurentian Great Lakes. PLoS One, 10(8): e0135146.

112. Kennedy, D.A. and Read, A.F. (2018) Why the evolution of vaccine resistance is less of a concern than the evolution of drug resistance. Proc. Natl. Acad. Sci. U. S. A., 115(51): 12878-12886.

113. Naylor, R.L., Hardy, R.W., Buschmann, A.H., Bush, S.R., Cao, L., Klinger, D.H., Little, D.C., Lubchenco, J., Shumway, S.E. and Troell, M. (2021) A 20-year retrospective review of global aquaculture. Nature, 591(7851): 551-563.

114. Lihan, S., Jamil, N.A., Jamian, M.A.H., Chiew, T.S., Ajibola, O.O., Justin, S., Benet, F. and Kion, L.N. (2020) Distribution and prevalence of antibiotic-resistant bacteria in fish farms in East Malaysia. Malays. J. Microbiol., 16(4): 263-274

115. Fauzi, N.N.F., Hamda, R.H., Mohamed, M., Ismail, A., Zin, A.A.M. and Mohamad, N.F.A. (2021) Prevalence, antibiotic susceptibility, and presence of drug resistance genes in Aeromonas spp. isolated from freshwater fish in Kelantan and Terengganu states, Malaysia. Vet. World, 14(8): 2064-2072.

116. Atyah, M.A.S., Zamri-Saad, M. and Siti-Zahrah, A. (2010) First report of methicillin-resistant Staphylococcus aureus from cage-cultured tilapia (Oreochromis niloticus). Vet. Microbiol., 144(3-4): 502-504.

117. Gudding, R. and van Muiswinkel, W.B. (2013) A history of fish vaccination: Science-based disease prevention in aquaculture. Fish Shellfish Immunol., 35(6): 1683-1688.

118. Eggset, G., Mikkelsen, H. and Killie, J.E.A. (1997) Immunocompetence and duration of immunity against Vibrio salmonicida and Aeromonas salmonicida after vaccination of Atlantic salmon (Salmo salar L.) at low and high temperatures. Fish Shellfish Immunol., 7(4): 247-260.

119. Midtlyng, P.J. (1996) A field study on intraperitoneal vaccination of Atlantic salmon (Salmo salar L.) against furunculosis. Fish Shellfish Immunol., 6(8): 553-565.

120. Kashulin, A., Seredkina, N. and Sørum, H. (2017) Coldwater vibriosis. The current status of knowledge. J. Fish Dis., 40(1): 119-126.

121. Midtlyng, P.J., Grave, K. and Horsberg, T.E. (2011) What has been done to minimise the use of antibacterial and antiparasitic drugs in Norwegian aquaculture? Aquac. Res., 42(s1): 28-34. 